\title{
FREEDOM OF ASSOCIATION AND COMPULSORY UNIONISM IN SWEDEN AND THE UNITED STATES
}

\section{Clyde W. Summers $\dagger$}

Collective bargaining in a democratic society rests on freedom of association which enables workers (and employers) to form organizations to represent their interests. Although commonly asserted by the organization, freedom of association is not simply a collective right vested in the organization for its benefit. Freedom of association is an individual right vested in the individual to enable him to enlarge his personal freedom. Its function is not merely to grant power to groups, but to enrich the individual's participation in the democratic process by his acting through those groups.

From the standpoint of individual rights and the democratic function of collective bargaining, freedom of association contains three distinct elements or forms of freedom. First is the freedom to organize - the right of individuals to join together to choose a single spokesman and to combine economic resources for their common good. This is the threshold right, for only through organizing can the individual in a collectivized industrial system participate meaningfully in the decisions which vitally affect his economic welfare. Second is the freedom to choose between organizations-the right of the individual to join and work through the organization which he believes speaks best for his needs and desires. This freedom of choice helps fulfill the purpose of the right to organize, for it enables the individual to give voice more clearly to his own wishes. By choosing between organizations, he participates in deciding which goals shall be sought and influences the decisions which affect him. Third is the freedom not to join any organization-the right of the individual to refuse to participate in collective action and to insist on acting alone.

These are three distinct freedoms, each subject to varying measures of protection and recognition in a collective bargaining system. More importantly, these three freedoms are not always mutually reinforcing; the strengthening of one may be at the expense

† Professor of Law, Yale University. B.S. 1939, J.D. 1942, University of Illinois ; LL.M. 1946, J.S.D. 1952, Columbia University. Member, New York Bar. 
of another. For example, the freedom of workers to organize fulfills its function only to the extent that the union can be effective in collective bargaining, but the freedom to choose between organizations requires rival unions which may fragment the workers' economic power in the babble of competing spokesmen. Similarly, the freedom not to join dilutes the freedom to organize by reducing the effectiveness of collective action. The clash between these freedoms is commonly expressed as a conflict between the union and the individual, but in a deeper sense it is a conflict between individual rights.

Sweden and the United States have both struggled with the problem of reconciling these competing claims, for in both countries collective bargaining rests broadly on freedom of association. Both countries view collective bargaining as more than a method of regulating the labor market; they each view it as a way of bringing a measure of democracy to industrial life. Both countries assert the worth of the individual and declare that the function of collective bargaining is to enlarge his freedom. In spite of these common premises and comparable systems of collective bargaining, the scope and content given to freedom of association in the two countries are significantly different. The difference is reflected both in the relative weights given to each of the three constituent freedoms and in the efforts made to reconcile or adjust their conflicting claims.

Both countries have confronted the problem in its boldest form. They approve "union security" or "organization" clauses in collective agreements, thereby requiring an individual to join or support the union as a condition of employment. Although both have placed legal limits on such provisions, the limits have not been the same. The cases which have arisen under these provisions emphasize the inherent difficulty of the problem and help reveal the relative weights given to the constituent freedoms.

By comparing freedom of association in two countries such as Sweden and the United States we may gain a clearer perspective of that freedom in both countries. The very similarity of democratic ideals and collective bargaining systems helps cast the special contours of that freedom in each country. It also makes us sharply aware of the different content which such a basic value may be given in democratic societies. Any meaningful comparison is difficult, for our concern is not with legal definitions but with social realities. The freedom actually enjoyed depends not only on the legal protection provided, but also on the recognition given these rights in practice by the parties. 


\section{Freedom of Association}

\section{A. The Freedom To Organize}

\section{Legal Protection}

Freedom of association is a constitutionally protected right in both Sweden and the United States, ${ }^{1}$ and this guarantee is commonly considered to include the right of workers to form unions for collective bargaining. ${ }^{2}$ The constitutional provisions, however, have limited significance, for they protect only against governmental acts, while the principal restraints on the right to organize have been imposed by employers. Protection must therefore rest either on the union's own economic strength or in legislation securing this right against private action.

Legislation protecting the right to organize has been enacted in both countries. Congress, in enacting the National Labor Relations Act in 1935, stated that right in broadest terms. Section 7 provides:

Employees shall have the right to self-organization, to form, join, or assist labor organizations, to bargain collectively through representatives of their own choosing, and to engage in concerted activities for the purpose of collective bargaining or other mutual aid or protection .... ${ }^{3}$

The Swedish Right of Association and Negotiation Act, ${ }^{4}$ enacted the following year, stated the right more abruptly: "The right of association shall not be infringed . . . " 5 The right was not defined

\footnotetext{
1 Sweden has no explicit provision equivalent to that in the first amendment that "Congress shall make no law . . . abridging ... the right of the people peaceably to assemble . ..."; but the right of association has generally been read into the general provisions of Article 16 of the Instrument of Government. See RoBBINs, The Government of Labor Relations In Sweden, 278 (1942). For discussions of this right in the United States, see Abernathy, The Right of Association, 6 S.C.L.Q. 32 (1953) ; Wyzanski, The Open Windoze and the Open Door: An Inquiry Into Freedom of Association, 35 CALIF. L. REv. 336 (1947).

2 See, e.g., Thomas v. Collins, 323 U.S. 516 (1945); AFL v. Reilly, 113 Colo. 90, 155 P.2d 145 (1944); Betänkande med Förslag till Lag om Förenings-och Förhandlingsrätt, SOU $1935: 59$, at 53, 103.

Citations in this Article to Swedish publications employ the abbreviations set forth in Schmidt, The Law of Labour Relations in Sweden 233 (1962) [hereinafter cited as SCHMIDT, LABOUR]. AD indicates Arbetsdomstolens domar (the Swedish Labor Court Decisions) ; SOU indicates Statens offentliga utredningar (command papers); N.J.A. is Nytt Juridiskt Arkiv (the Swedish Supreme Court Reports).

349 Stat. 452 (1935), as amended, 29 U.S.C. $\S 157$ (1958). The economic and political antecedents of this statute are traced in BernsteIn, The New DeAl CoLLeCTIVE BARgaining Policy (1950). 251-58.

4 Svensk Författningssamling, 1936 nr. 506, translated in Schmidt, Labour

5 Sch midt, Labour 251.
} 
because the Riksdag could not agree on a definition, ${ }^{6}$ and the Labor Court was compelled to give it specific content through judicial decisions. ${ }^{7}$ In 1940 the right was legislatively defined as, "the right of employers and employees to belong to an association . . . , to exercise their rights as members . . . , and to work for an association or for the formation of an association." 8 Although the right to organize is expressed in similar statutory terms in both countries, the legal protection in the two countries is significantly different. The right to organize in Sweden is in legal theory rooted in the individual, and the organization has no independently protected legal right. ${ }^{9}$ Employer tactics directed at undermining and destroying the union are not prohibited unless they also violate an employee's individual right to freedom of association. ${ }^{10}$ The union's right to damages is derivative only, and depends upon a showing of wrong to an individual. ${ }^{11}$ In the United States the right is both individual and collective. Although the statute protects the individual, it gives the union independent protection. In practice, the protection is primarily collective, and in refusal to bargain cases it is solely collective.

The range of employer conduct prohibited is also much narrower in Sweden than in the United States. For example, a Swedish employer, unlike his American counterpart, can post watch over union meetings, plant spies inside the union, grant unilateral increases, or make individual contracts with employees in order to discourage union organization. There are no Swedish cases limiting the employer in what he can say to his employees concerning unionization, or in what he can ask them concerning union membership. ${ }^{12}$ Nor are there any cases holding that employees have a right to distribute union pamphlets and solicit union membership in the plant and in the parking lot on

6 The legislative debates are traced in Betänkande med Förslag till Ändring i Lagen om Förenings-och Förhandlingsrätt, SOU 1939:49, at 16-25.

7 See AD $1937: 73$.

8 Svensk Författningssamling, $1940 \mathrm{nr}$. 332, in Schmidr, LABour 251.

9 Section 3 of the Right of Association Act defines violations as "measures . . . to constrain any employee or employer, as the case may be . . ." See $\dot{A} D$ 1946:68 (violation by a union of an employer's right of association).

10 See generally Schmidt, LABour 129, 136.

11 SOU $1939: 49$, supra note 6 , at 71 . The individual whose rights are violated, however, need not be a member of the union but may be one outside the union who is induced not to join.

12 Threats made to specific employees to discharge them if they join the union can be a violation of the statute, see SCH MIDT, LABOUR 175, but the Labor Court has been willing to overlook such threats on the ground that they were made in the heat of the moment and not seriously meant, AD 1953:30. The employer can declare his dissatisfaction with the employees' joining the union, AD 1953:19, tell them that if they do not join another union with lower wages he may have a layoff, AD $1945: 92$, urge them to join the competing union, AD 1943:95, or question them as to their union membership, AD 1939:68. 
nonworking time. ${ }^{13}$ Favored unions may be assisted or employercontrolled unions created, since Swedish law has no provision parallel to section 8 (a) (2) prohibiting employers from dominating or interfering with the formation or administration of unions.

The protection of the Swedish statute does not reach much beyond Section 8(a) (3) of the National Labor Relations Act-protection against discrimination in employment designed to interfere with the employee's freedom of association. ${ }^{14}$ Although the kinds of employer conduct prohibited ${ }^{15}$ and the legal rules developed ${ }^{16}$ in Sweden are similar to those in the United States, the protection actually provided against discrimination is not the same. For example, a Swedish truck driver who joined the union and then insisted on being paid according to the collective agreement was denied relief when he was discharged. The Swedish Labor Court conceded that his exercise of statutory rights was the immediate cause of his discharge, but held that since he was slow, clumsy, and in some degree dull-witted, the employer was entitled to replace him with a competent worker if he were to claim the union scale. ${ }^{17}$ In contrast, an American truck driver who was an active union leader was discharged after he was found taking gasoline from his truck. The NLRB found that the discharge was motivated in part by his union activities and ordered him reinstated with back pay. ${ }^{18}$ In another Swedish case, an employer paid lower wages to members of one of two competing unions and told them they could not be paid more until they joined the other union. The Swedish Labor Court found no violation on the ground that the employer did not do this for the purpose of causing them to leave their union, even though

13 See Republic Aviation Corp. v. NLRB, 324 U.S. 793 (1945) ; cf. United Steelworkers v. NLRB, 357 U.S. 357 (1958); NLRB v. Babcock \& Wilcox Co., 351 U.S. 105 (1956).

14 From 1929 to 1956 there were 185 cases brought to the Labor Court claiming employer violation of the right of association. Of these, 160 were cases of dismissal, and the rest involved claims of lesser forms of discrimination. GEIJER \& SCHMIDT, ARBetagivare oCh FACKFöreningsledare i Domarsäte 43 (1958).

15 For example, it is a violation for an employer to discriminate against union members by paying them lower wages, AD 1936:78, denying them promotions, AD $1955: 16$, transfering them to less desirable work, $A D$ 1953:39, giving them less overtime work, AD 1948:52, or giving them a bad letter of recommendation, AD 1953:36. It is also a violation to require an employee to agree not to join a union, AD 1951:46, to offer an increase on condition that the employee leave the union, AD 1958:35, or to state in a work certificate that he is a union member when this may interfere with getting another job, AD 1936:78.

16 The statutes in both countries require an objective element. In the United States there must be an "act of discrimination," and in Sweden a "measure." Both statutes also require a subjective element of intention or motive to interfere with the freedom of association.

17 AD $1943: 116$; see AD $1953: 30$.

18 NLRB v. Ford, 170 F.2d 735 (6th Cir. 1948); see Edward G. Budd Mfg. Co. v. NLRB, 138 F.2d 86 (3d Cir. 1943). 
it had that effect. ${ }^{19}$ In a similar case, the United States Supreme Court found an employer guilty of an unfair labor practice for paying greater benefits to union members than to nonunion employees. ${ }^{20}$ The Court declared that he was deemed to intend the foreseeable consequences of his conduct and the natural consequences of his conduct were to encourage or discourage membership in the union. Thus, although the employer's motive is crucial in both countries, the kind of motive required and the evidence necessary to prove that motive is quite different. $^{21}$ The employer's conduct is more strictly circumscribed and more closely scrutinized by the NLRB than by the Swedish Labor Court.

Another difference can be found in Sweden's failure to protect those seeking employment. The employer can refuse to hire job applicants because of their union membership, since the individual's right of association is said to depend on the employment relation. ${ }^{22}$ The union has no legal recourse even though the employer's systematic discrimination in hiring undermines or destroys it, for its rights are only derivative and discrimination in hiring does not constitute a violation of the individual's right. ${ }^{23}$ In the United States, the job seeker is entitled to the same protection as the job holder. It is as much a violation for an employer to discriminate because of union membership in hiring as in discharging. In the words of the Supreme Court:

Discrimination against union labor in the hiring of men is a dam to self-organization at the source of supply. The effect of such discrimination is not confined to the actual denial of employment; it inevitably operates against the whole idea of legitimacy of organization. ${ }^{24}$

In Sweden, the employer's right to organize is considered the equivalent of the employee's right and is protected in the same statutory terms. In a leading case, the union refused to contract with a small employers' association which was not affiliated with the Swedish Employers' Federation (SAF), and insisted that the employers involved sign individual contracts. To avoid a threatened strike, the employers joined an association which was affiliated with SAF and with which the union had an agreement. The Labor Court held that the union, by refusing to contract with the unaffiliated organization,

19 AD 1942:72.

20 Radio Officers' Union v. NLRB, 347 U.S. 17 (1954).

21 See cases cited note 12 supra.

22 See Schmidt, Labour 134; SOU 1939:49, supra note 6, at 70.

23 Schmidt, Labour 136; SOU 1939:49, supra note 6, at 71-72.

24 Phelps Dodge Corp. v. NLRB, 313 U.S. 177, 185 (1941). 
had violated the employers' freedom of association, since one of the principal benefits of this freedom was having the association as a party to collective agreements. ${ }^{25}$ The Wagner Act, in contrast, does not even mention the right of employers to organize, and the Taft-Hartley Act contains only the isolated provision that it is an unfair labor practice for a union "to restrain or coerce . . . an employer in the selection of his representatives for the purpose of collective bargaining or the adjustment of grievances . . . ." 26 It is not clear to what extent, if any, this protects the right of employers to join together for mutual aid and protection. ${ }^{27}$ There is clearly no common acceptance that the employer's right is the full equivalent of the employee's right.

\section{De Facto Protection}

Except for the explicit protection given employers, legal protection of the right to organize is much narrower in Sweden than in the United States. A bare comparison of legal rules, however, fails to measure the extent to which that right is in fact recognized and enjoyed in the two countries.

Swedish employers at first bitterly resisted unionization. Union members were discharged and evicted from company-owned houses; employees were required to sign "yellow dog" contracts in which they agreed not to join a union. The employers also refused to recognize or deal with unions, and formed "company" or "yellow" unions which they controlled. ${ }^{28}$ However, with the rise of centralized employers' associations at the turn of the century, particularly the Swedish Employers' Federation (SAF), the prevailing attitude changed. ${ }^{29}$ Employers who organized felt compelled to recognize an equivalent right of workers to organize, ${ }^{30}$ and the basic assumption of the employers'

25 AD 1946:68.

26 Labor-Management Relations Act §8(b) (1), 61 Stat. 140 (1947), 29 U.S.C. $\S 158$ (b) (1) (1958).

27 See NLRB v. Local 499, Teamsters Union, 353 U.S. 87 (1957) (under certain circumstances, employers may engage in concerted economic action of lockout); Metropolitan Dist. Council of United Bhd. of Carpenters, 137 N.L.R.B. 1583 (1962) (union may not compel an employer to accept an association as his representative); United Ass'n of Journeymen of Plumbing Indus., 135 N.L.R.B. 462 (1962) (union may not compel members of one association to be represented by another association); Hoisting \& Portable Eng'r Union, 132 N.L.R.B. 648 (1961) (union may refuse to bargain with association as multiemployer representative); General Teamsters Union, 127 N.L.R.B. 488 (1960) (union may not refuse to bargain with association and insist on individual contract: $\rightarrow$ Meltzer, Lockouts Under the LMRA: New Shadows on an Old Terrain, 28 U. CHI. L. Rev. 614 (1961).

28 Adlercreutz, Kollektivavtalet 230-35 (1954) ; Robbins, The Government of LABOR RELATIONS 70 (1942).

29 AdLerCReutz, op. cit. supra note 28, at 242-43. (1927).

30 Hallendorff, Svenska Arbetsgivareföreningen 1902-27, at 12, 16, 50 
associations was that labor must be dealt with collectively through workers' organizations. ${ }^{31}$ Thus, when the SAF learned that a labor conflict involving one of its members had been caused by the employer's refusal to allow his employees to join the union, it refused to give the employer any financial aid or other support. ${ }^{32}$

In 1906 a number of bitter and prolonged strikes growing out of the union's efforts to prevent the employment of nonunion workers led to the negotiation of the famous "December Compromise" between the Swedish Employers' Federation and the Confederation of Swedish Trade Unions. ${ }^{33}$ This agreement declared that, "The right of association shall be left inviolate on both sides." It further provided that, "If the workers believe that discharge has occurred under circumstances which may be interpreted as an attack on their right of association, they may, before further steps are taken, through their organization call for an investigation for vindication of their rights." 34 Thereafter, provisions guaranteeing these rights were commonly included in collective agreements, and the great majority of employers recognized the right of workers to organize. With the enactment of the Collective Contracts Act of 1928, provisions in collective agreements guaranteeing freedom of association became legally enforceable. $^{35}$ Even in the absence of an explicit contractual provision, the Labor Court held that such a provision must be implied because the employer's obligation to respect the right of association was inherent in the legal nature of the collective agreement. ${ }^{36}$

By 1936 nearly 90 percent of all manual workers were unionized and covered by collective agreements. They therefore enjoyed practical recognition and legal protection of the right to organize. ${ }^{37}$ The Right of Association Act of 1936 simply extended legal protection to employees not covered by collective agreements-primarily agricultural workers, clerical workers, and salaried employees. Since the passage of the statute, most Swedish employers have fully accepted the right of association. Violations of the statute are now quite rare, with

31 Id. at $31,41$.

32 Id. at 74 .

33 Id. at 75-84; AdLERCREUTz, op. cit. supra note 28, at 344-48.

34 Whether this last provision gave the union only the right to call for an investigation or gave it the right to call for negotiations, leading eventually to arbitration was unclear and led to conflicting views by the parties. See ScHMIDT 126; ADLERCREUTZ, $o p$. cit. supra note 28 , at 347-50.

35 See, e.g., AD 1931:107 (discharge for organizing activity); AD 1933:30 (requiring employees to sign "yellow dog" contracts). The cases are collected in SOU 1939:49, supra note 6, at 48-62, and RoBBINs, op. cit. supra note 1, at 287-305. 36 AD 1935 :57; AD 1935 :94; GIEJER \& Sch MIDT, op. cit. supra note 14, at 35-36.

37 See Betänkande med Förslag till Lag om Förenings-och Förhandlingsrätt, SOU $1935: 59$, at $74-103$. 
only four or five cases being brought to the Labor Court each year. Nearly 95 percent of all manual workers and 80 percent of all salaried employees are now unionized. Thus, the right to organize is in fact fully recognized and enjoyed.

The right to organize in the United States is in fact far less complete. Historically, American employers combated unionization with all of the methods used at first by Swedish employers, but instead of abandoning these tactics, American employers refined and reinforced them. Employers' associations were not organized to deal with unions, but to destroy them $;^{38}$ union leaders were discharged and blacklisted; and "company unions" were systematically promoted as a part of the "American plan." ${ }^{39}$ In this contest over unionization, the courts often curbed the unions' counter measures. ${ }^{40}$ Strikes to compel reinstatement of discharged union leaders were declared illegal ; ${ }^{41}$ union efforts to persuade employees who had signed "yellow dog" contracts to join the union were enjoined; ${ }^{42}$ and picketing, no matter how peaceful, was denominated coercive and prohibited. ${ }^{43}$ In 1935 , when the National Labor Relations Act was passed, only 13 percent of all nonagricultural employees were union members. ${ }^{44}$ This act was not, like its Swedish counterpart, the statutory declaration of a generally recognized right to organize; instead it was an attempt legally to establish and protect a right commonly denied. However, employer resistance to unionization did not end with the passage of the act. Even today, many

38 See generally Bonnetr, Employers Associations in the United States (1922). Prior to 1900, employer associations willing to negotiate with unions predominated, but hostile associations subsequently became more prevalent. Even the National Metal Trades Association, the most militant antiunion organization, began as a negotiating association but became distinctly belligerent in 1901. Id. at 24 .

39 For a brief description of employer antiunion tactics see Bernstein, The Lean Years 144-89 (1960); Twentieth Century Fund, Labor and Government 51-64 (1935). For more extended descriptions see HubERMAN, THE LABOR SPY Racket (1937); Levinson, I Break Strikes (1934). Such activities in the 1930's were extensively explored by the La Follette Committee. See Senate Comm. on Education and Labor, Violations of Free Speech and Rights of Labor, S. REP. No. 46, 75th Cong. 1st Sess. (1937).

40 See generally Frankfurter \& Greene, The Labor Injunction 1-46 (1930);

Witte, The Government In Labor Disputes 12-60 (1932); Magruder, $A$ Half Century of Legal Influence Upon Development of Collective Bargaining, 50 Harv. L. REv. 1071 (1937). In contrast, the courts in Sweden were almost totally neutral, limiting neither the union's nor the employer's use of economic force in disputes over organization or terms of agreement. ADLERCREUTz, op. cit. supra note 28, at $227-31$.

41 See, e.g., Mechanics Foundry \& Mach. Co. v. Lynch, 236 Mass. 504, 128 N.E. 877 (1920).

42 Hitchman Coal \& Coke Co. v. Mitchell, 245 U.S. 229 (1917) ; UMWA v. Red Jacket Consol. Coal \& Coke Co., 18 F.2d 839 (4th Cir. 1927).

43 See, e.g., Atchison T. \& S.F. Ry. v. Gee, 139 Fed. 582 (C.C.S.D. Iowa 1905);

Keith Theatre v. Vachon, 134 Me. 392, 187 At1. 692 (1936); Cooper, The Fiction of Peaceful Picketing, 35 Mich. L. Rev. 73 (1936).

44 U.S. Dept. of Commerce, Historical Statistics of the United States 98 (1962). 
employers use every method within the letter of the law to prevent unionization or to undermine existing unions. ${ }^{45}$ Various business organizations distribute publications advising employers how to frustrate union organizing efforts; ${ }^{46}$ certain lawyers become specialists in helping employers combat the union and defeat it in an election; and "labor consultants" may provide the employer with a captive union. ${ }^{47}$ In fact, some employers are willing to use antiunion devices that are not within the limits of the law, and will commit even the most flagrant violations rather than tolerate a union. The NLRB during its last fiscal year issued 1,102 complaints of unfair labor practices against employers, and an equal number of charges were settled prior to the issuing of the complaint. ${ }^{48}$ In 1962, 3,351 employees who had been discriminatorily discharged were offered reinstatement in their jobs and employers were required to pay a total of nearly two and a half million dollars in back pay. ${ }^{49}$ It is evident that in many shops and communities a worker joins a union at his peril.

Legal protection of the right to join a union is much broader and more comprehensive in the United States than in Sweden, but the scope of legal protection is more a product of the lack of the right to organize than a measure of its actual existence. The law has curbed, but has not overcome employer resistance; the individual's freedom of association, so far as it involves the right to join a union, is in fact much greater in Sweden than in the United States.

\section{B. The Freedom To Choose Between Organizations}

The law of both countries recognizes that the freedom of association includes the freedom to choose between organizations. Section 7 of the National Labor Relations Act states that, "Employees shall have the right . . . to bargain collectively through representatives of their own choosing." Section 3 of the Swedish Right of Association Act provides that it is a violation of the individual's right of association "to cause him not to enter or to leave an association or not to make full use of membership . . . ." Under both statutes it is as much a

45 See Barkin, The Decline of the Trade Union Movement and What Can Be Done About It 75 (1961); Wyle, Union Organization Activity Under TaftHartley, in N.Y.U. 11th ANN. Conf. on LABOR 191 (1958).

46 See, e.g., Georgia State Chamber of Commerce, Preventative MedicineA Prescription for Management To Use in Treating Unionitis (1959); Ten Specific Steps Designed To Block Mill Unionization, American Textile Reporter, May 19, 1960, p. 75.

47 See S. REP. No. 1417, 85th Cong., 2d Sess. 255-300 (1958).

48 NLRB General Counsel, Summary of Operations 21 (1962).

49 NLRB General Counsel, Press Release, Jan. 6, 1963. 
violation for an employer to favor the members of one union over members of another as it is to favor nonunion employees.

The individual does not, however, have complete freedom of choice in either country. In the United States, freedom of choice is qualified by the principle which makes the union selected by the majority of the employees in the bargaining unit the exclusive representative of all employees in the unit. ${ }^{50}$ Once a majority union is designated, the individual's freedom of choice is suspended. ${ }^{51} \mathrm{He}$ can, of course, remain a member of another union, but it is hollow membership. The other union cannot bargain or contract for him, nor can it handle his grievances or consult with his employer. ${ }^{52} \mathrm{He}$ is compelled to accept the majority union as his sole representative, and he is bound by its collective agreements. ${ }^{53}$

Within the framework of majority rule, freedom of choice is a guiding principle, and the law is shaped to protect that right. Majority status is often determined by a secret ballot, and the National Labor Relations Board enforces "strict standards designed to assure that participating employees have an opportunity to register a free and untrammelled choice . . . ." ${ }^{54}$ Coercive conduct, an atmosphere of fear, even material misstatements or "campaign trickery" may so impair the reality of freedom of choice as to void the election..$^{55} \mathrm{Al}$ though the employer may state his preferences between unions, he can give no advantages to one during the campaign nor indicate that he will deal with them differently in making a contract. ${ }^{56}$ After the election, freedom of choice is only temporarily suspended, for the losing union may obtain a new election when the collective agreement expires,

50 Section 9(a) provides: "Representatives designated or selected for the purposes of collective bargaining by the majority of the employees in a unit appropriate for such purposes, shall be the exclusive representatives of all the employees in such unit for purposes of collective bargaining in respect to rates of pay, wages, hours of employment, or other conditions of employment." 49 Stat. 453 (1935), as amended 29 U.S.C. \$159(a) (1958). (1945).

51 Weyand, Majority Rule in Collective Bargaining, 45 Colum. L. Rev. 556

52 Hughes Tool Co. v. NLRB, 147 F.2d 69 (5th Cir. 1945).

53 Comparison of Swedish and American law on this point is discussed more fully in Summers, Collective Power and Individual Rights in the Collective Agreement-A Comparison of Swedish and American Law, 72 Yale L.J. 421 (1963).

5426 NLRB Ann. Rep. 70 (1961) ; see Funke, Board Regulation of Pre-Election Conduct, 36 Texas L. Rev. 893 (1958).

5526 NLRB Ann. Rep. $72-74$ (1961) ; NLRB v. Trancoa Chem. Corp., 303 F.2d 456 (1st Cir. 1962). The election may be invalidated even though the employer's conduct is not an unfair labor practice but is privileged as "free speech" under section 8(c). General Shoe Co., 77 N.L.R.B. 124 (1948); Sewell Mfg. Co., 138 N.L.R.B. 12 (1962).

56 Checker Taxi Co., 131 N.L.R.B. 611 (1961); Lenscraft Optical Corp., 128 N.L.R.B. 807 (1960). 
or has been in force for three years, whichever occurs sooner. ${ }^{57}$ The principle of freedom of choice further influences the Board in limiting the size of the bargaining or election unit. The statute requires that professional employees be placed in a separate unit and entitles them to be represented by their own union unless they vote to be represented by the same union as the nonprofessional employees. ${ }^{58}$ The Board has given skilled craft employees substantial freedom to be represented separately by traditional craft unions, and has also allowed various departmental and other groups of employees within a plant to vote separately to designate representatives of their own choosing lest they be submerged in a larger bargaining unit. ${ }^{59}$ Even though an employer has several plants doing similar work, the employees in each plant are frequently allowed to choose separate bargaining representatives. ${ }^{60}$ Multiple employer units are established only when the employees of each employer have chosen a common union. ${ }^{61}$ The effect of creating separate units or election districts is to increase the ability of small groups to choose their own representative and thereby reduce the impact of majority rule on the basic right of freedom of choice.

The justification for applying majority rule, with its inevitable limitation on freedom of association, is simply that experience has demonstrated that without such a rule the right to organize would be of little value. Bitter rival unionism, particularly when aggravated and exploited by employers, frustrated collective bargaining and left unions impotent. Only by designating one union as sole spokesman could collective bargaining be established and the right to organize made meaningful. ${ }^{62}$ The various legal rules concerning the frequency of elections, the size of the bargaining units, and other details represent an uneasy balance between freedom of choice and the practical needs of collective bargaining.

Swedish legal theory preserves in purer form the principle of free choice. The law of collective agreements reflects the individualistic concept of contract law that a man cannot be bound without his

5726 NLRB ANn. Rep. 39-51 (1961). The Board has recently lengthened the contract bar rule from two years to three years. General Cable Corp., 139 N.L.R.B. 1123 (1962).

58 NLRA §9(b), 49 Stat. 453 (1935), as amended, 29 U.S.C. 159(b) (1958). The same section also requires that plant guards must be placed in separate units and that no union be certified as the representative of the guards if it admits to membership, or is affiliated with, an organization which admits to membership employees other than guards.

59 See 26 NLRB Ann. Rep. 54-65 (1961).

${ }^{60}$ See Daykin, Determination of Appropriate Bargaining Units by the NLRB: Principles, Rules and Policies, 27 Fordham L. Rev. 218 (1958).

61 See Summers, supra note 53, at 430.

62 Houde Engineering Corp., 1 N.L.R.B. (old) 35 (1934). 
consent. The individual consents to the collective agreement when he joins the union. ${ }^{63}$ A union, therefore, can bargain only for its members, and the collective agreement is legally binding only on the union members. ${ }^{64}$ Each union in a plant can make a separate agreement which governs its own members. The individual thus has full freedom to bargain through the representative of his own choosing.

This legal theory, however, does not in practice bar one union from effectively prescribing terms and conditions of employment for members of another union. One union may provide in its collective agreement that the employer shall apply the same terms to all employees regardless of union membership. Such a provision is valid, and any violation by the employer makes him liable to the contracting union. ${ }^{65}$ Because members of another union are not considered parties to this contract, they remain legally free to bargain through their own union and make a different agreement which is equally binding on the employer ${ }^{66}$ If the two collective agreements conflict, the presence of one does not excuse violation of the other; and the employer cannot escape liability in damages to one or the other of the unions. ${ }^{67}$ This preserves the theory of freedom of contract but not its reality, for no employer will straddle the legal sword of inconsistent contracts. In practice, the weaker union is compelled to conform to the contract of the stronger; the employee's freedom is merely to choose the scrivener of the contract. $^{68}$ It has never even been suggested that the attempt of one union thus to regulate the terms and conditions of employment of members of another union was an invasion of their right to bargain through representation of their own choosing. On the contrary, the Labor Court has held that even without such a provision there is an implied obligation on the empioyer to give all employees the benefits provided in the collective agreement. ${ }^{69}$

These legal rules, which give one union effective control and limit the individual's freedom to choose his bargaining representative, have their roots in economic realities. Even if a union's collective agreement could not legally regulate beyond the union's own membership, it would in fact do so. To pay different rates and give varying benefits to employees working side by side in the same plant would create not

59 (1959).

63 See Adlercreutz, op. cit. supra note 28, at 5; Schmidt, Tjänsteavtalet 31,

64 Bergström, Kollektivavtalslagen 70 (1948); Schmidt, Labour 112.

65 Schmidt, TJänSteavtalet 41 (1959).

66 AD 1939:24.

67 AD 1939:24; AD 1937:149.

68 See, Summers, supra note 53, at 427-31.

e9 AD 1931:93; AD 1932:95; AD 1944:37; AD 1952:8. 
only administrative confusion in management but also disruptive tensions in the work group. Efficient production and employee satisfaction require standardization of terms and conditions of employment. One union must inevitably dominate, and one agreement must establish the controlling terms. ${ }^{70}$ The United States and Sweden have both arrived at this result-one directly by making the majority union the exclusive representative, the other indirectly by allowing a union to make a contract applicable to nonmembers. The critical difference is the way in which the controlling union is determined. Instead of allowing the workers to determine their bargaining representative by a majority vote in a closely supervised election, Sweden permits effective representation to depend on the relative economic strength of the competing unions, weighted by the employer's preference among unions. $^{71}$ The structure of bargaining in Sweden magnifies this difference. Few employers attempt to bargain alone, but instead bargain through employers' associations, organized typically along industry lines on a national basis. ${ }^{72}$ These associations negotiate national agreements for each industry with the parallel national unions of the Swedish Confederation of Labor (LO).$^{73}$ Thus, in practice, the bargaining units are nationwide and other unions cannot effectively challenge them on the national level. Furthermore, the employers' associations have historically favored bargaining with the unions affiliated with the two major federations and have resisted bargaining with competing unions. $^{74}$ If a competing union at the local level insists that a particular employer deviate from the national agreement, it will be confronted by the massed economic resources of the employers' association. Even though all of the employees of the particular employer join the competing union, the employers' association will generally refuse to sanction any agreement which varies from the national agreement negotiated with the affiliated unions. Thus, workers employed by a

70 Several unions may bargain jointly through a committee or cooperate in other ways in negotiating for an enterprise or industry, but each union is the spokesman for its particular category of employees, and the terms for those employees are standardized.

71 The contrast is emphasized by the Supreme Court decision in International Ladies' Garment Workers' Union v. NLRB, 366 U.S. 731 (1961), which held that it was an unfair labor practice for an employer to recognize a union as the representative of his employees when it in fact did not have a majority, even though both the employer and the union mistakenly believed it had a majority. The contract made with the union was held unlawful and the employer was ordered to withdraw recognition until after the Board held an election.

72 Swedish Employers Confederation, Perspective of Labor Conditions in SWEDEN (1962).

${ }^{73} \mathrm{LO}$ negotiates for manual workers, and the national unions of the Salaried Employees Central Organization (TCO) negotiates for white collar workers. The structure of bargaining is described in Johnston, Collective Bargaining in Sweden (1962).

74 See Summers supra note 53, at 428-29. 
member of an employers' association have no practical freedom to choose which union shall negotiate the controlling agreement. They are in fact governed by the LO and TCO regardless of their choice. In addition, the employees have no freedom to choose between unions within the major federations. LO has full power to define the jurisdiction of its member unions and can assign workers in particular trades or enterprises to a certain union. ${ }^{75}$ As the lines are drawn or changed, workers are required to transfer from one union to another to conform to these lines. ${ }^{76}$ The boundary between LO and TCO unions is not so rigidly drawn, but an agreement between the two federations has eliminated almost all competition and stifled the freedom of employees to choose between the two unions. ${ }^{77}$

In the United States some of these same forces tend to limit the actual freedom to choose between unions, but on a much smaller scale. The American labor movement has been characterized by rival unionism. $^{78}$ For twenty years the AFL and the CIO bitterly contested for members. Within the federations, national unions competed with each other because neither federation had the power to make binding decisions on jurisdiction. ${ }^{79}$ Some of this rivalry has been muted by the merger of the federations, and, through its no-raiding pact, the AFL-CIO has sought to reduce competition between member unions by providing for binding arbitration of disputes over representation rights. ${ }^{80}$ In the Textile Workers case, ${ }^{81}$ the court enforced an arbitrator's award ordering one of two competing unions to ask the NLRB to remove its name from the ballot in a pending election. This effectively deprived the employees of any freedom to choose between possible representatives. ${ }^{82}$ The no-raiding pact, however, is a

75 Stadgar För LandSorganisationen I Sverige sec. 6, mom. 3, sec. 14, mom. 2 ; JoHnston, op. cit. supra note 73 , at 66 .

76 StADgar FÖr LANDSORganisationen I Sverige sec. 11, mom. 2, sec. 14, mom. 1.

77 See Karlbom, Den Svenska FackFöreningSRÖrelsen 305-06 (1955); JoHNsTon, op. cit. supra note 73 , at 106 . For further efforts to eliminate boundary disputes see LO Kongress Protokol, motions 51, 52, at 288-90 (1961). TCO has more troublesome boundary problems with a third federation of professional or academically trained persons, Sveriges Akademikers Centralorganisation (SACO). See ILO, The Trade Union Situation in Sweden 36 (1961); Sjöberg, Organisatoriskt kaos utanför Teleförbundet, 1960:40 FACKFÖRENINGSRÖRELSEN 221-24.

78 See generally Galenson, Rival Unionism (1940).

79 Krislov, Union Organizational Rivalry Among American Unions, 13 IND. \& LAB. ReL. Rev. 216 (1960) ; Weber, Competitive Unionism in the Chemical Industry, 13 Ind. \& LAB. Rel. REv. 16 (1959); Lehrer, The CIO Jurisdictional Dispute Experience, 11 Ind. \& LaB. Rel. Rev. 246 (1958); Jaffe, Inter-Union Disputes in Search of a Forum, 49 YALE L.J. 424 (1940).

80 See Goldberg, AFL-CIO: Labor United 76-83, 271-82 (1956); Cole, Jurisdictional Issues and the Promise of Merger, 9 Ind. \& LAB. ReL. Rev. 391 (1956). 1958)

81 United Textile Workers v. Textile Workers Union, 258 F.2d 743 (7th Cir.

82 For a discussion of the operation of the no-raiding pact and its treatment by the NLRB, see Aaron, Interunion Representation Disputes and the NLRB, 36 TExAS L. REv. 846 (1958). 
relatively meager restraint. It does not reach unions such as the Teamsters which are outside the federation, and even within the federation it binds only those national unions which voluntarily join. Moreover, it does not apply to efforts to organize plants hitherto unorganized, but prevents competition only where one union already has an established bargaining relationship. The no-raiding pact cannot compare with LO's nearly complete power to draw the boundary lines between member unions, and is far less effective than the working agreement between $\mathrm{LO}$ and $\mathrm{TCO}$ to allocate organizational rights. Freedom of choice may be further limited in the United States by the lack of competing unions in many occupations or industries. Workers have little or no choice between unions in construction, trucking, railroads, music, or printing; and they often have no practical choice in the steel, rubber, automobile, and garment industries. Even so, rival unionism remains substantial in the United States, but is nearly nonexistent in Sweden. The reality of choice is suggested by the fact that each year approximately 1,000 NLRB elections involving two or more unions are held, with some 150,000 workers voting. ${ }^{83}$

Pattern bargaining in the United States has some of the same impact as national agreements in Sweden, for the union which sets the pattern limits the freedom of unions which are forced to follow. ${ }^{84}$ These patterns, however, lack the rigidity of Swedish national agreements even on strictly economic issues such as wages. In addition, collective agreements in the United States tend to cover a much wider range of subjects than in Sweden. Included are such matters as seniority, discharge, vacations, pensions, and health and welfare benefits. ${ }^{\mathbf{8 5}}$ This provides much more flexibility to bargain both for noneconomic terms and for the allocation of economic benefits. Although American unions must follow the pattern, they can be more than scriveners scrupulously copying the agreements of other unions. They have an actual ability to represent, and the freedom of the workers to choose is therefore more than empty form.

The freedom to choose between unions is not complete in either Sweden or the United States, for both the legal rules and the structure of bargaining are molded by practical needs. The legal rules in the United States deliberately limit full freedom by the principle of majority rule, but within that framework the freedom has substantial

8326 NLRB Ann. Rep. Table 13A (1961).

84 See Ross, Trade Union Wage Policy (1948); Seltzer, Pattern Bargaining and the United Steelworkers, 59 J. PoL. Econ. 322 (1951).

85 In Sweden, collective agreements covering industrial workers commonly do not cover these subjects which are governed either by statute or left to management prerogative. However, collective agreements covering white collar workers do generally cover these subjects. See ILO., op. cit. supra note 77, at 63-65. 
reality. The legal rules in Sweden build upon the individualism of freedom of contract, but when contracts are made by collective entities such as the strong national unions and national employers' associations, there is little individual freedom to choose any other representatives.

\section{The Freedom Not To Join a Union}

Simple logic, reinforced by the appeal of verbal symmetry, makes the conclusion seemingly self-evident that freedom of association includes the freedom not to associate. Indeed, from the standpoint of the individual, protection of the right to organize and the right to choose between organizations provides less than full freedom if there is no protection to remain outside all organization. This, however, assumes that the central purpose of protecting freedom of association is to provide each separate individual full freedom of action. The law may, on the contrary, seek quite another goal. The principal or sole purpose may be to aid individuals to join together for collective action. In that case, it may protect the right to join, but not the right to remain outside, since the purpose of aiding collective action is not furthered by protecting those who reject collective action. Both Sweden and the United States, in enacting their basic labor laws, have struggled with these competing viewpoints as to the purpose of their respective statutes. Their contrasting conclusions reflect their different concepts of freedom of association in labor and industrial relations.

The Swedish Freedom of Association Act of 1936 was preceded by seven years of study and public debate. The initial focus was the "third man's" right to neutrality in economic conflicts, and the emphasis was on protecting outsiders from being conscripted by battling collective groups. Underneath ran a deep concern for the individual's right of self-determination within a society dominated by large economic organizations. The proposals brought forth by the experts and commissions assigned to study the problem not only limited the use of economic force against the "third man" generally, but gave special protection to the right of association. ${ }^{86}$ This right was conceived in terms of individual self-determination, and was defined as including both the right to join and the right to remain outside an association. ${ }^{87}$ These proposals applied not only to unions and employer associations, but also to organizations of other economic groups such as farmers,

86 Utredning Angående Tredje Mäns Rätt till Neutralitet i Arbetskonflikter, SOU 1933:36; Betänkande med Förslag till Lag Angående Vissa Ekonomiska Stridsåtgärder M.M., SOU 1934:16.

87 SOU 1933:36, at 136-37, 147; SOU $1934: 16$, at 11, 27. 
tradesmen, and renters. Such organizations had effectively used the boycott and other forms of collective action to compel other individuals to join and to conform to collective decisions. ${ }^{88}$ These organizations, along with the unions, resisted legal limitations on their use of economic force, and the proposed legislation was defeated in a maelstrom of political controversy. ${ }^{89} \mathrm{~A}$ few months later, another expert commission brought forth a proposal to protect the right of association and collective bargaining only in the labor market. ${ }^{90}$ Like the earlier proposals, it defined the right of association as the "right to belong or not to belong" to an association and prohibited the use of economic force "to compel or hinder anyone to enter or withdraw from an association." ${ }^{91}$ The Confederation of Trade Unions supported the proposal generally, but opposed any protection of the right not to join. ${ }^{92}$ The Government's bill followed this line, defining the right of association as "the right to belong" and making it a violation only if measures were taken against a person "to hinder him from entering or to compel him to withdraw from an association." The central purpose of the legislation, it was argued, was to protect the right of workers to bargain collectively; the right of association ought to be regulated only to the degree necessary for securing the right to bargain collectively. Protection of the right not to join was a part of the larger problem of limiting the use of collective force against third persons and did not logically belong in the statute. ${ }^{93}$

The commission's proposal thus focused on the individual's right of self-determination and the government's bill focused on the value of collective action. One sought to protect the individual's full freedom of action; the other sought to protect only his right to organize for collective bargaining. The Riksdag evaded the issue. The statute, as enacted, contained the Delphic declaration that, "the right of association shall be inviolate," but contained no definition of that right or what constituted a violation..$^{94}$ This fundamental question was shunted by default to the Labor Court. Confronted by the task of completing the statute, the Labor Court felt bound to follow the pattern of existing law and looked to the content of the right of association which it

88 See SOU 1933:36, at 56-84; Heckscher, Staten och Organisationerna 88-89 (1951).

89 See Westerstånl, Svenska FackFöreningsrörelSEN 397-404 (1945).

90 Betäkande med Förslag till Lag Om Förenings-och Fördhandlingsrätt, SOU $1935: 59$.

$91 \mathrm{Id}$. §4. See also id. at 107, 115-16.

92 Id. at $160-61$.

93 Proposition No. 240 (1936); Andra Lagutskottets Utlåtande No. 58 (1936). 94 The history of this provision is traced in SOU 1939:49. 
had held was an implied term in every collective agreement. ${ }^{95}$ The focus was therefore solely on the right essential to the existence of a collective bargaining relationship-the right to join together for collective action. The statutory right, thus shaped by the Labor Court in the image of the right implied in the collective contract, did not include the right of the individual to remain outside the collective relationship. ${ }^{96}$

In 1940, the statute was amended to make the Labor Court's rule explicit. The right of association was defined as the "right to belong to an association," and a violation consisted of compelling a person "not to enter or to withdraw from an association." The individual was unprotected from economic pressures to compel him to enter or remain in a union. This partial protection of the right of association, it was argued, was all that was appropriate in a statute which had as its purpose securing the right to bargain collectively. More comprehensive protection of the right, including the right not to belong, should await further studies then in progress. ${ }^{97}$ These other studies came to nought and the law remains unchanged-the individual has no right to remain unorganized.

The current of developments in the United States has been in the opposite direction. When the National Labor Relations Act was passed in 1935, the concern was not with the power of unions, but the lack of effective unions. $^{98}$ It was not necessary to protect the individual from collective groups, but rather to establish collective bargaining, and the stated purpose of the act was to encourage "the practice and procedure of collective bargaining." 99 Section 7 stated the rights of employees only in the affirmative- "the right to self-organization, to form, join or assist labor organizations, to bargain collectively . . . and to engage in concerted activities." Although section 8(3) protected the right not to join a union by making it an unfair labor practice for an employer by discrimination in employment "to encourage or discourage membership in any labor organization," it expressly permitted a majority union to make an agreement requiring membership in the union as a condition of employment. The most significant restriction on the individual's freedom to remain outside the collective structure was the exclusive representation rule. The individual

95 See AD 1937:73.

96 AD $1937: 73$; AD $1937: 150$.

97 SOU 1939:49, supra note 6, at 65 .

98 See Bernstein, The New Deal Collective Bargaining Policy 1-17, 84-99, 100-11, 129-52 (1950).

99 NLRA § 1, 49 Stat. 449 (1947), as amended, 29 U.S.C. §151 (1958). 
could, in the absence of a union security clause, refuse to become a member of the majority union, but he could not escape being bound by its contract. Even here, however, he retained a small measure of independence, for section 9 (a) provided that "any individual employee or group of employees shall have the right at any time to present grievances to their employer."

In the Taft-Hartley amendments of 1947, the individual's freedom to refrain from collective action became a dominant theme. In addition to the basic rights to organize, bargain collectively, and engage in concerted action, section 7 added a parallel "right to refrain from any or all of such activities." The statute made it an unfair labor practice for a union "to restrain or coerce . . . employees in the exercise of their rights guaranteed by section 7." 100 If employees became dissatisfied with collective bargaining, they could obtain an election, by majority vote decertify the union, and revert to individual bargaining. ${ }^{101}$ Section 9 (a) gave the individual increased freedom to process his own grievances and have them adjusted without the intervention of the majority union. The right of association was thus implicitly, but unmistakably, defined as including the right to remain unassociated, and the right not to join any union was equally protected with the right to choose between unions. Indeed, it is sometimes said that the policy of the statute is no longer to encourage collective bargaining, but to protect employees in their freedom of choice as to whether they shall have collective bargaining. This freedom, however, is still subject to majority rule; the individual is, even against his will, bound by the wishes of the majority in the bargaining unit.

The Taft-Hartley Act further protected those who chose not to join or be represented by a union when it restricted the secondary boycott and thereby curtailed the unions' use of economic pressure to achieve representative status. ${ }^{102}$ Some unions had traditionally refused to handle goods made in nonunion shops, to receive deliveries made by nonunion deliverymen, or to work on buildings in which nonunion workers were employed by other employers. ${ }^{103}$ By reducing the em-

100 LMRA § 8(b) (1), 61 Stat. 141 (1947), 29 U.S.C. §158(b) (1) (1958).

101 LMRA §9(e), 61 Stat. 145 (1947), 29 U.S.C. §159(e) (1958).

102 LMRA § 8(b) (4), 61 Stat. 141 (1947), 29 U.S.C. §158(b) (4) (1958). Secondary boycotts had previously been subject to various restrictions under state law. See Hellerstein, Secondary Boycotts in Labor Disputes, 47 YALE L.J. 341 (1938); Note, Labor's Use of Secondary Boycotts, 15 Geo. WASH. L. Rev. 327 (1947). State law was displaced by the federal statute. San Diego Bldg. Trades Council v. Garmon, 359 U.S. 236 (1959). Although this changed details in the pattern of restrictions, it probably did not work any major change.

103 See Wolman, The Boycott in American Trade Unions (1916); Laidler, Boycotts aNd the Labor Struggle (1914). 
ployment opportunities of those who were not union members, the union brought economic pressure on them to join. These boycotts were sometimes used as sympathy measures in aid of a strike called by a majority union. More often, however, they were directed against enterprises in which the union did not have a majority, the purpose being to bring economic pressure on the employees to accept it as their bargaining representative. ${ }^{104}$ Although the Taft-Hartley Act curbed such measures in the name of protecting neutral employers, the individual's right not to join or be represented received substantial protection. The Landrum-Griffin amendments in 1959 not only tightened these restrictions on secondary boycotts, but also blunted another economic weapon used by unions to obtain representative status-so-called organizational picketing. ${ }^{105}$ The union, by placing pickets in front of an establishment in which a majority of employees are nonunion, seeks to persuade potential customers not to buy, deliverymen not to deliver, and servicemen not to enter. If such picketing is effective, it can threaten the enterprise with destruction; and destruction of the enterprise means destruction of employment. The nonunion employees, in order to save the business and their jobs, are compelled to accept the union as their bargaining agent. This device is now more closely limited by section $8(\mathrm{~b})(7)$ which has as its articulated purpose the protection of the individual's freedom to choose which, if any, union shall represent him. ${ }^{106}$

What the union seeks through various forms of secondary boycott and organizational picketing is to extend its representative status or bargaining power to employees in bargaining units in which it does not have a majority. Like the Swedish union, it seeks to regulate terms and conditions of employment of individuals who do not choose to be so regulated and whom the union is not legally authorized to

104 See Brinker \& Cullison, Secondary Boycotts in the U.S. Since 1947, 12 LAB. L.J. 397 (1961). Section 8(b) (4) (B) permits a certified union to use secondary economic pressure to compel an employer to recognize and bargain with it, but $\S 8(\mathrm{~b})(4)$ (C) prohibits the use of primary pressure to compel recognition when another union has been certified.

105 Labor-Management Reporting and Disclosure Act §8(b) (7), 73 Stat. 544 (1959), 29 U.S.C. $\$ 158$ (b) (7) (Supp. IV, 1962). Prior to the statute, state courts had imposed varying limitations on such picketing probably of equal restrictiveness. Bornstein, Organizational Picketing in American Law, $46 \mathrm{Ky}$. L.J. 25 (1957). See also, Meltzer, Recognition-Organizational Picketing and the Right-To-Work Laws, 9 LAB. L.J. 55 (1958).

106 The uncertain limits on such picketing were mapped out in Cox, The LandrumGriffin Amendments to the NLRA, 44 MINN. L. Rev. 257 (1959); Note, Picketing by an Uncertified Union: The New Section 8(b)(7), 69 Y ALE L.J. 1393 (1960). What the Board has made out of this section, and is still remaking, is suggested in Weiss, The Unlarvful Object in 8(b)(7) Picketing, 13 LAB. L.J. 787 (1962) ; Comment, Appeals to the Consumer: The Remaining Area of Permissible Organizational Picketing Under Section 8(b)(7), 9 U.C.L.A.L. Rev. 666 (1962). 
represent. ${ }^{107}$ While the Swedish unions are legally free effectively to encompass all employees in the relevant labor market-in practice substantially the entire industry-, American unions are generally restricted to regulating employees in the statutory bargaining unitcommonly a small fragment of the competitive labor market. Although American law has not wholly prohibited the union from using economic pressure to extend its representative status or bargaining control, it has worked out no rational or intelligible body of rules to reconcile the individual's freedom to remain outside the collective structure with the union's interest in making its agreements applicable to employees beyond the narrowly defined boundaries of the bargaining unit. Swedish law has avoided these difficult problems simply by permitting the dominant national union to make its agreements practically binding on all employees regardless of their choice.

The freedom not to join may be viewed at two distinct levels. The first is the freedom of the individual to stand outside the collective structure, to bargain for himself, and not be governed by the union's collective agreement. The second is the freedom of the individual who is governed by the collective agreement to refuse to be a member of the union, to be bound by its rules, or to contribute to its support. At the first level, the Swedish worker has little freedom in fact. Collective agreements blanket almost the entire labor market, and whether he is a member or not, his terms and conditions are controlled by the union's collective agreement. The American worker can much more readily remain beyond the union's control. Although collective agreements legally bind all in the bargaining unit, they cover only one-third of nonagricultural workers, and blanket only a limited number of industries such as steel, auto, rubber, railroads, trucking, and maritime trades. In practical terms, the American worker can choose to reject collective bargaining but the Swedish worker cannot. The second level of the freedom not to join depends upon the extent and legality of collective agreements-union security or organization clauses-which require the worker, as a condition of his employment, to belong to the union or contribute to its support.

\section{Union Security or Organization Clauses}

The problem of freedom of association is cast in its boldest form when the collective agreement makes a worker's employment depend

107 See Isaacson, Organizational Picketing: What Is the Law?-Ought the Lare To Be Changed?, 8 Buffalo L. Rev. 345 (1959). To such efforts the Board has now given its stamp of approval under the label of "area standards picketing." International Hod Carriers Union, 133 N.L.R.B. 512 (1961); Houston Bridge \& Constr. Trades Council, 136 N.L.R.B. 321 (1962); Local 344, Retail Clerks Ass'n, 136 N.L. R.B. 1270 (1962). 
on his membership or support of the union. By compelling his adherence to one union, it denies the individual both the freedom to choose between unions and the freedom to remain outside a union. The justification given for this limitation of freedom is that it strengthens the particular organization and makes association more effective.

Contract provisions to this end-commonly referred to as "union security" clauses in the United States and as "organization" clauses in Sweden-not only pose fundamental questions of freedom of association, but also raise sharp issues of management prerogatives. From the employee's viewpoint, every organization clause encroaches on his freedom to choose which, if any, union he will join. From the employer's viewpoint these provisions encroach on his freedom to choose which workers he will hire or retain. The closed shop agreement which requires the employer to hire only union members, particularly when coupled with the union-operated hiring hall, gives the union great control over the selection of employees. The union shop agreement which requires all employees to join, and remain members of, the union gives the union the power to compel the discharge of employees it deems undesirable by refusing them admission to, or expelling them from, the union. Even the agency shop agreement which requires all employees to pay a "bargaining fee" equal to union dues, compels an employer to discharge an employee whom he finds otherwise suitable, because the employee has failed to make the required payment to the union. Union security or organization clauses are thus at the center of two of the most troublesome areas in collective labor relationsthe right of the individual within the collective labor relations system and the allocation between unions and management of control over that system.

This convergance of the issues of individual rights and management prerogatives has made union security in the United States a vortex of controversy, with the two contributing issues wholly confused. The battle over union security has been bitter on both legal and economic fronts and continues with unabated if not increased vigor. So-called "right to work" laws have been the center of heated political debate, with nineteen states adopting such laws, twenty states rejecting them, and four states first enacting and then repealing them. ${ }^{108}$

108 Sultan, Right-To-Work Laws-A Study in Conflict 56-61 (1958). The following states have such laws: Alabama, AlA. CoDE tit. 26, § 375 (1958) ; Arizona, Ariz. Const. art. xxv, Ariz. Rev. Stat. Ann. § 23-1301 (1956) ; Arkansas, Ark. Const. amend. 34, ARK. Stat. \$ 81-201 (1960) ; Florida, Fla. Const. § 12; Georgia, Ga. Code AnN. §54-801 (1961); Indiana, Ind. AnN. Stat. § 40-2701 (Supp. 1961); Iowa, Iowa Code ANN. § 736A.1 (Supp. 1962) ; Kansas, Kan. Const. art. 15, §12; Mississippi, Mrss. Const. art. 7, §198-A ; Nebraska, NeB. Const. art. xv, §§ 13-15, 
Union security was a central issue in the Taft-Hartley debates. Except for banning the closed shop, Congress never fully resolved the issue, and it now plagues both Congress and the courts. At the bargaining table the controversy has often been equally bitter. In 1952, in the midst of the Korean crisis, the entire steel industry was shut down for seven weeks because of a dispute over whether a union security clause should be included in the collective agreement.

In Sweden, organization clauses are neither the subject of political debate nor the source of economic conflict. No legislation regulating such clauses has been seriously discussed since the Right of Association Act was amended in 1940. Organization clauses are seldom a significant issue in collective bargaining and are never productive of a substantial strike. The controversy, so far as it exists, is a legal one fought in the courts; the adversaries are not union and management, but the LO unions and the competing Syndicalist unions. This litigation raises basic issues of freedom of association, but it is on the outer fringes of the labor relations system. The obvious question is, how did Sweden achieve such tranquility in this area which has proven so turbulent in the United States.

\section{A. Union Security as a Union-Management Issue- A Study in Contrast}

Some early Swedish unions sought to protect their members from competition for jobs by unorganized workers. These unions succeeded in obtaining scattered agreements, particularly in the building, bakery, and stevedoring industries, which required the employer to give job preference to union members. ${ }^{109}$ The great majority of employers saw such clauses as threats since they challenged the employer's right to determine whom he would engage "and would make the employers in all of their business management and production dependent on the workers and their leaders." 110 The labor movement as a whole did not applaud these provisions. The movement's dominant socialist outlook frowned on efforts by one group of workers to obtain a monopoly on jobs to the exclusion of other workers. Protectionism

Neb. Rev. Stat. §48-217 (1959); Nevada, Nev. Rev. Stat. §613.230 (1961); North Carolina, N.C. Gen. Stat. \$ 95-78 (1958); North Dakota, N.D. Cent. Code § 34-01-14 (1960) ; South Carolina, S.C. CoDE \& 40-46 (1962); South Dakota, S.D. CoDE § 17.1101 (Supp. 1960) ; Tennessee, Tenn. Code AnN. \$50.208 (1955); Texas, Tex. Rev. CIv. Stat. art. 5207a (1962); Utah, UTAH CODE ANN. \$ 34-16-1 (Supp. 1963);

Virginia, VA. Code ANN. §40-68 (1953); Wyoming, Wyo. Laws 1963, ch. 39. The Louisiana right to work law applies only to agricultural employees. LA. REv. Stat. ANN. \$23.889.1 (Supp. 1962).

109 LindBom, DEN SvenSKa FackFöreningsrörelsens UppKomst och Tidigare HistoRIA 315-18 (1938).

110 AdLerCReutz, Kollektivavtalet 251 (1955). 
was condemned as a violation of class solidarity. ${ }^{111}$ This demand for solidarity, however, carried a threat to management prerogative in another form. Members refused to work with, and forced employers to discharge, those who failed to show solidarity by working during a strike or refusing to join the union. ${ }^{112}$

These efforts by unions to enforce solidarity led the Swedish Employers' Federation to amend its constitution in 1905 to include the important section $23 .{ }^{113}$ This section provided that every employer member in making a collective agreement "shall include a provision that the employer has the right to freely engage and dismiss workers, to direct and allot the work, and to employ workers belonging to any union or to none." The motivations for this amendment were set forth in the circular proposing it:

From the labor unions' side there is carried on a persistent effort for the purpose of usurping the power to determine which workers an employer must use, and the unions wish also to reach the point where the union through its representative in the plant shall be able to influence the direction of the work. This is a demand to which an employer can never surrender. . . . The employers also have an obligation to those workers who are not organized or who do not belong to those organizations which have affiliated with LO or in the Social Democrat Party, to protect with all power the freedom of contract. ${ }^{114}$

Section 23 triggered a series of bitter strikes which finally led the national confederations, SAF and LO, to negotiate the December Compromise of $1906 .{ }^{115}$ Under this agreement, which left a deep and permanent imprint on Swedish labor relations, the employers won recognition of their right to manage as expressed in section 23 . At the same time, unions won express recognition of their right of association and protection against being discharged for union activities. Organization clauses were thus wholly rejected, but the right to organize fully accepted. The Compromise took the form of a provision to be

111 Westerståhl, Svenska FACKFÖREningsRÖRElsen 28-29 (1945). There was some tendency during the period of mass unemployment in the 1920's and 1930's for unions to attempt to monopolize available jobs, but the policy of solidarity was vigorously reaffirmed by $\mathrm{LO}$, and all unions were required, as a condition of their affiliation with LO, to maintain open membership. KARLBOM, DEN SvenskA FACKFöreningsRÖRELSEN 206-09 (1955); Stadgar FÖR LANDSORGanISATIONEN I SverIge sec. 11, mom. 2.

112 AlderCREUTz, op. cit. supra note 110, at 246-49. 23 (1939).

113 Now section 35 . For a general study of this provision, see Åman, PARAGRAF

114 Hallendorff, Svenska Arbetsgivareföreningen 58 (1927).

115 See notes 33-34 supra. 
included in collective agreements. This provision remains today as a standard clause in the majority of Swedish collective agreements. ${ }^{116}$

The December Compromise points to two significant contrasts between Swedish and American experience in dealing with this troublesome issue at the bargaining table. First, Swedish unions and employers both saw the central issue as one of management prerogatives. Although employers at times talked of "the freedom of work" and stated that "the right of the unorganized worker must be provided for," 117 these were largely makeweight arguments. The issue was treated as a part of the larger problem of the union's right to participate in the decisions of the enterprise, and was resolved by the unions' conceding to management the prerogatives asserted in section 23 , thereby withdrawing their claim to a voice in determining who should be hired or retained.

On the other hand, disputes over organization clauses in the United States are commonly fought on moral grounds, with the employer playing the self-appointed role of guardian of individual rights. ${ }^{118}$ In the steel strike during the Korean crisis, the president of U.S. Steel declared, "if the day ever comes when a man-in order to earn his living-must join one particular church, one particular party, or one favored union, then we may as well join forces with Russia . . . ." 119 In the same vein was a statement by the steel companies justifying their refusal to give in to the union's demands: "We are shedding our blood and spreading our treasure in foreign lands for the sake of individual freedom. This freedom at home must be protected from every threat." ${ }^{120}$ The unions have countered with the moral claims that the union has the right of survival and that all workers for whom the union bargains and whom the union is obligated to represent should pay

116 Management's right of unquestioned control over discharges was somewhat softened by the Basic Agreement of 1938, negotiated between LO and SAF, which stated general guides to be followed in dismissals and layoffs. See SCHMIDT, LABOuR 263-77. In such cases the union can call for negotiation and ultimately appeal to the Labor Market Board, a body made up of an equal number of representatives of unions and employers associations with no impartial member. Its function is primarily conciliatory, and in twenty years only 40 cases have been appealed to it, with 13 cases coming to a decision. This device has not proved satisfactory to the unions, for they have been compelled to accept what little the employers were willing to concede. See Sch MIDT, TJänSTEAvtalet 142-48 (1959). In 1961, LO finally resolved to make a determined effort to change this by requiring employers to show objectively acceptable grounds for dismissals and by obtaining binding arbitration in such cases. See FACKFÖRENINGSRÖRELSEN OCH FÖRETAGSDEMOKRATIN (1961); LO Kongress Protokoll 299-319, 372-79 (1961). The outcome of this effort is still uncertain.

117 HallendoRFF, op. cit. supra note 114, at 57-58; AdLERCREUTz, op. cit. supra note 110 , at 251 .

118 See Toner, The Closed Shop 115-47 (1942).

119 Sultan, Right-To-Work Laws: A Study in Conflict 55 (1958).

120 Ibid. 
their share of the costs. ${ }^{121}$ Moral issues are far from ideal subjects for collective bargaining, since public compromise then becomes awkward. The severity of the impasse has been manageable only because both sides have often been willing to surrender their moral claims for less noble but more tangible gains.

The claim of management prerogatives has been understandably subdued, if not wholly silent, in these disputes. Employers in the United States have long conceded to unions a voice on dismissals and job assignments. Collective agreements commonly contain seniority clauses, prohibit discharge except for cause, and regulate job transfers and promotions. Indeed, employer insistence on a section 23-type provision would approach a refusal to bargain in good faith. ${ }^{122}$ The encroachments on management prerogatives of a legitimate organization clause are negligible when compared with the encroachments of other clauses which the employer regularly accepts. ${ }^{123}$ The employer's resistance has therefore been placed on grounds of individual rightsan issue which is not readily negotiable and leads to bitter conflict.

The December Compromise's recognition of the Swedish unions' right to organize presents the second marked contrast between Swedish and American experience. The Compromise endured because the Swedish Employers' Federation genuinely accepted collective bargaining, did not attempt to undermine unions, and denied aid to employers who engaged in antiunion activities. In fact, employers within SAF actively encouraged their employees to join the LO unions. As a result, union membership within SAF has customarily been more complete than with other employers. ${ }^{124}$ Thus, even the management prerogatives asserted by section 23 do not give the unions a sense of insecurity.

While Swedish employers were negotiating the December Compromise, American employers were launching their "open shop" offensive. Although directed at compulsory unionism, the attack was on a broader front. An open shop meant not merely rejection of the closed shop, but refusal to recognize the union. ${ }^{125}$ Union members

121 See Toner, op. cit. supra note 118, at 148-75; AFL-CIO, Union Security -The Case Against the Right To Work Laws (1958).

122 Cf. NLRB v. American Nat'l Ins. Co., 343 U.S. 395 (1952) ; Order of Ry. Telegraphers v. Chicago N.W. Ry., 362 U.S. 330 (1960); Town \& Country Mfg. Co., 136 N.L.R.B. 1022 (1962).

123 See Slichter, Healy \& Livernash, The Impact of Collective Bargaining on MANAGEMENT 947-51 (1960); Chamberlain, The Union Challenge to Management Control, in Management Rights and Labor Arbitration: A Symposium, 16 IND. \& LAB. REL. REV. 183, 184-92 (1963).

124 WeStersti at $116-28$.

125 See Sultan, op. cit. supra note 119 , at $21-30$; Toner, op. cit. supra note 118 , 
would be hired, but if they struck they would be discharged, and collective bargaining was considered dealing with the devil. The position was baldly stated by the head of United States Steel Corporation in 1919 when the union requested a meeting with management. "As you know, we do not confer, negotiate with, or combat labor unions as such. We stand for the open shop." ${ }^{126}$ American employers thus bitterly resisted that which Swedish employers early conceded-the right to organize and bargain collectively. Union demands for closed or union shop were motivated largely by the fear that employers would undermine the union by replacing members with nonmembers. Organization clauses were, in the American context, properly labelled "union security" clauses, for they were the union's shield in its continuing struggle for survival. The dispute remains virulent not only because of its historic bitterness, but also because unions still feel insecure and must often fight for their very lives. ${ }^{127}$

Union and employers in Sweden resolved the issue of organization clauses by a basic compromise in which employers secured their right to manage and unions secured their right to organize. Their vital collective interests settled by bargaining, they left the issue of individual rights to be settled by legislation. In the United States, the employer has asserted the right of the individual worker to choose whether he will join, and the union has asserted its right to security. The issue in collective bargaining has thus been the two competing aspects of freedom of association - the right of individual freedom of choice and the right to effective organization. This dilemma becomes practically insoluble when the union fears, with substantial justification, that the employer is asserting individual rights to weaken or disintegrate collective action.

Other factors reinforce these differences in the nature of the problem in the two countries. Since unionization is almost complete in Sweden, the union's collective power is not weakened by the few who remain outside. In the United States, organization is incomplete, and workers lack a sense of moral or social responsibility to support the union. In addition, the presence of competing unions aggravates the sense of insecurity. The fact that employees are able to choose between unions causes the unions to seek contract provisions which limit that freedom of choice.

126 Taft, The A.F. of L. in the Time of Gompers 387 (1957).

127 This does not mean that demands for union security clauses disappear when the union becomes secure. Even the railroad brotherhoods which have been organizationally secure for nearly 30 years, and have obtained that security without any such help, still insist on the union shop. 


\section{B. The Extent of Compulsory Unionism}

Although section 23 only binds members of the Swedish Employers' Federation, it exemplifies the dominant pattern. Other employer associations, such as those in commerce, forestry, and newspaper publishing, follow the SAF policy of prohibiting organization clauses. In white collar industries such as banking and insurance, the problem does not exist because the salaried employees' unions have not generally sought such clauses. The problem is also nonexistent in collective agreements with national, provincial, and local governments because the unions believe that organization clauses violate the principle of equal opportunity in public employment.

In spite of this dominant pattern, organization clauses do present a significant problem in some branches of industry. ${ }^{128}$ In the shipping industry, agreements commonly provide that employers may hire only union members. If none are available the employer is required to cooperate with the union in organizing nonunion seamen who are hired. Most collective agreements with the various cooperative enterprises require employees to join the union. In the building industry, about thirty percent of all workers are employed by employers outside the Swedish Employers' Federation, and almost all of these are covered by some form of organization clause-some with a closed shop, but the majority with a union preference clause. In trucking, in which there are many small employers who do not belong to the employers' association, organization clauses are common. The exact extent of such clauses in Sweden is not known, for no comprehensive study has been made. It is quite clear, however, that although these clauses cover less than ten percent of all private employment, they are common in significant segments of industry. It is also clear that the LO unions generally seek such clauses when they are not blocked by firm employer association policies. ${ }^{129}$

Although a collective agreement may not contain an organization clause, employment may in fact be conditioned on union membership. On the waterfront, employment is channelled through a hiring hall, operated by the stevedore employers' association, a member of SAF

128 The tendency is to assume that the SAF position makes this problem one of academic interest only. See ILO, The Trade Union Situation in Sweden 31-32 (1961); Johnston, Collective Bargaining in Sweden 48 (1962). But see Schmidt, LABOUR 136; WeSTERSTÅHL, op. cit. supra note 111, at 164-67.

129 Some trades, such as barbering, hairdressing, and chimney cleaning, have so-called "mutual organization" clauses which not only obligate the employer to hire only union members but also obligate union members to work only for members of the employers' association. 
technically bound by section $23 . .^{130}$ Workers are classified for purposes of job priority as "ordinary," "extra," or "casual." For a worker to advance from "casual" to "extra," or from "extra" to "ordinary," he must wait for a vacancy to arise and then apply to the employment office. If the union objects to the applicant, it makes its objections known to the office. Although the employers are nominally free to choose the worker to fill the vacancy, the union's objections are not lightly disregarded lest this lead to difficulties on the job. The union cultivates the impression, reinforced by practice, that applicants who are not members of the union will not be approved and thereby enforces a virtual closed shop among regular harbor workers. In other industries, employers may respond to similar, though more subtle pressures. Many employers who belong to SAF and are bound by section 23 in fact give hiring preference to members of LO unions because they wish to maintain good relations with the union and avoid possible friction in the work force.

Except in the stevedoring industry, hiring halls are rarely used, and employers seldom look to the union to provide needed workers. Instead, reliance is placed largely on the state employment service, even in the shipping, building, hotel, and restaurant industries, in which labor turnover is high. The use of the state employment service, however, does not always solve the problem for workers who do not belong to LO unions. ${ }^{131}$ The agency's "golden rule" is to "provide employers the kind of workers desired." If the employer indicates that he prefers union members, the agency cooperates by excluding nonmembers. In addition, it has been claimed by the Syndicalists that the local offices of the service are often administered by former officials of the LO unions who have at times discriminated against Syndicalists. In addition to using the state employment service, the building industry, particularly in Stockholm, often hires on a gang basis, with the employer dealing directly with a gang leader to provide a group of workers of a particular craft. This system invites discrimination, for the work gang may refuse to take in those who are not union members. ${ }^{132}$

130 The hiring system is described in detail in AD 1955:16.

131 See AD 1950:27 for the difficulties of Syndicalist seamen applying for work through the state employment office.

132 This danger is mitigated, however, by the prevalence of the piece rate or incentive system of pay in the building industry. Because the incentive pay is normally on a gang basis, the members of the gang are more concerned with their follow workers' productivity than with their political or union affiliation. Increased earnings provide a sufficient base for group solidarity. A Syndicalist who is a fast worker is often welcome in a working gang of LO members. 
Although organization clauses cover but a small segment of Swedish industry, their presence is puzzling. Swedish unions do not need such clauses to protect themselves from employer attack. Nor are "free riders" who accept the union's benefits, but refuse to share its burdens, a substantial problem. ${ }^{133}$ At times, unions have sought to obtain a monopoly of available jobs, but this policy, which has been rejected, becomes self-defeating when the union has organized 95 percent of the labor market. In spite of this, unions seek organization clauses whenever employer resistance is not rigid. This is, in part, a reflection of a deep-rooted dissatisfaction with anything less than 100 percent solidarity and a particular antipathy for any form of rival unionism. Organization clauses have as their principal target the little band of Syndicalist unions which remain a thorn in the side of the LO unions. The justification for compelling them to join proceeds from the premise that the $\mathrm{LO}$ union is in fact the exclusive bargaining agent. Thus, when it was proposed at the Sheet Metal Workers convention that reprisals should not be imposed on those who for idealistic reasons joined the Syndicalists, the rationale was starkly stated: Such a worker was a "scab," and if he gets the benefits of the contract he should belong "after which he may have whatever ideals he will." ${ }^{134}$

The extent of union security clauses in the United States has formed quite a different pattern. ${ }^{135}$ Although employers have condemned such provisions as immoral and a violation of individual rights, they have shown a marked tendency, once the union was established, to grant the union's demand. In 1941, the number of workers covered by some form of union security clause represented 40 percent of all those under collective agreements. ${ }^{136}$ During World War II, the extent of union security agreements greatly increased, aided by the War Labor Board's policy of resolving disputes over this issue by ordering maintenance of membership clauses. ${ }^{137}$ When the Taft-

133 Even without an organization clause, it is difficult for a man to remain outside the union. The social pressure to join when almost all his fellow workers belong is extremely strong, and the worker comes to assume that when he takes a job he will also join the union. In the Municipal Workers Union, which has nearly $100 \%$ organization, it was found that $10 \%$ of the members were distinctly hostile to the union and perhaps a fifth would not have joined if they had felt fully free to do as they pleased. LindBlad, SvEnSKa KommUnalarbetareförBunDET 388-96 (1960). See also Heckscher, Staten och Organisationerna 87-89 (1951). (1960).

134 Svenska Bleck-och Plåtslagareförbundets Kongress Protokoll 72

135 See generally TONER, op. cit. supra note 118, at 58-92.

136 Peterson, Extent of Collective Bargaining at Beginning of 1942, 54 MoNTHLY LABOR REV. 1066 (1942).

137 See Seidman, American Labor From Defense to Reconversion 91-108 (195: $\rightarrow$ Jaffe, Union Security: A Study of The Emergence of Law, 91 U. PA. L. Rev. 275 (1942). 
Hartley Act was passed, 78 percent of all employees working under collective agreements were covered by some form of union security device. $^{138}$ That statute did not reverse the trend, for a representative sample eleven years later showed that the percentage so covered had risen to more than 80 percent. ${ }^{139}$

The contrast betwen the two countries is thus sharpened. In the United States, although only a minority of employees are covered by collective agreements, nearly all of those covered are bound by union security provisions. In Sweden, nearly all employees are covered by collective agreements, but only a small minority are bound by organization clauses. From the viewpoint of the individual, the choice in the United States is whether he shall be governed by collective bargaining. Once that choice is made affirmatively by the majority in the appropriate unit, he will normally have no choice but to support the majority union. In Sweden there is no practical choice whether to be governed by collective bargaining, but there is normally a choice whether to join the union.

\section{Legal Limits on Organization Clauses in Sweden}

The right of association, protected by the Act of 1936, limits the legality of unions' and employers' conditioning employment on union membership. That right, however, is so circumscribed as to give substantial room for the operation of organization clauses. As was previously discussed, the statute protects the individual's right to choose between unions, but it does not protect his right to remain unorganized. Thus, an employer who makes a contract containing an organization clause with an LO union cannot lawfully discharge a member of the Syndicalists, but must discharge a worker who belongs to no union. ${ }^{140}$ Furthermore, the statute protects only those who are employed, not those seeking work. ${ }^{141}$ Thus, an employer who has agreed to hire only members of an LO union cannot discharge Syndicalists he has inadvertently hired, but neither can he hire a worker who is not a member of the LO union. ${ }^{142}$

138 Bureau of Labor Statistics, Extent of Collective Bargaining and Union ReCognition (Bull. 909, 1946).

139 Theodore, Union Security Provisions in Major Union Contracts, 1958-59, 82 Monthly Labor Rev. 1348 (1959).

$140 \mathrm{AD} 1945: 30$. If an employee leaves the LO union and joins the Syndicalists, he cannot be discharged, AD 1954:15, but if he simply fails to pay his dues or is expelled without joining another union, he can be discharged, AD 1959:17; AD $1952: 16$.

141 SOU $1939: 49$, at 70.

142 AD 1952:18. 
Although the worker who is employed is fully protected in his choice of unions, this protection continues only for the life of the job. When employment ends, he loses his statutory shield and becomes a defenseless job seeker. The Labor Court has been niggardly in extending statutory protection and has been markedly reluctant to find that successive jobs for the same employer amount to continuous employment. In one case, a Syndicalist construction worker had been employed in digging test holes for a proposed garage. When the ground proved inappropriate, he was told that new plans would have to be drawn and new tests made on another site about one hundred yards from the first. He was to told to "inquire concerning the work later on." Nine days later he heard that the employer had hired two new workers who were LO members. When he inquired, he was told that he was not given the work because the employer was required by an organization clause to hire only LO members. The Labor Court declared that because lay-offs were not generally used in the building industry, the Syndicalist's employment should be treated as having been terminated, and that the refusal to rehire was therefore no violation of his right of association. ${ }^{143}$ In another case, a construction employer told a Syndicalist worker that when the building was finished, he would be sent with the crew to another location if he would join the LO union to comply with the organization clause. Although it was customary for an employer to move an entire work crew from one building to another, the Labor Court held that the employment in this case was for only one job at a time, and that the transfer to a new location was new employment. There was, therefore, no violation. ${ }^{\mathbf{1 4 4}}$

The Labor Court has not been quite so dryly logical in dealing with employment on the waterfront. Harbor workers who hold cards as "ordinaries" or "extras" have been declared to be employees even though they constantly move from job to job, because the Court has recognized that such cards, in fact, provide the workers with regular employment. Refusal to give jobs to workers holding such cards, or refusal to promote from "extra" to "ordinary" because the workers are Syndicalists, is therefore a denial of the right of association. However, those holding cards as "casuals" are held not to be employees,

143 AD $1951: 21$.

144 AD 1949:72. It is questionable whether these decisions fulfill the intention of those who drafted the statute. The commission report, in explaining the statute, stated that "the real relation ought to be decisive and not the choice of words which are used. Similarly it ought to be noted that even if on a shutdown a dismissal of the work force must be considered to have occurred, a refusal on a later resumption to recall the workers could under special circumstances constitute a violation of the right of association". SOU 1939:49, at 70-71. The Labor Court has been more lenient in finding continuous employment where seasonal workers have been rehired year after year. AD 1959:10; AD 1944:97. 
and refusal to promote them to "extras" because of union membership does not violate the statute. ${ }^{145}$ Thus, Syndicalists can be systematically barred from achieving the status which would ensure them regular employment.

These decisions defining the legal limits of organization clauses make clear that members of a competing union such as the Syndicalists get little practical protection. ${ }^{146}$ Members are protected for the duration of their jobs, but organization clauses exist primarily in industries such as building or shipping, which typically have short-lived jobs. The worker is then blocked from further employment until he joins the LO union. The Court's restrictive application of the statute aggravates its failure to protect the job-seeker, and the individual is often left without protection.

The most marked characteristic of the organization clause cases is the ambivalent attitude shown by the Labor Court to the individual's right to choose which union to join and support. The court is composed of two representatives from the major labor federations, LO and $\mathrm{TCO} ;{ }^{147}$ two representatives from the employers' associations; and three public members. The court at times has been unable to find in the law any protection for competing unionism, more specifically the Syndicalists. ${ }^{148}$ This tendency is especially apparent in the union and employer members on the court. When the act was first passed, union members on the court insisted that an organization clause in a collective agreement overrode the statutory right of association of Syndicalist employees. ${ }^{149}$ The union members eventually obtained the support of the employer members, and the court held that employees hired after a contract had been signed could be discharged under an organization clause, even though they belonged to the rival union. ${ }^{150}$ This position was reversed by amending the statute in 1940 explicitly to provide that the employer and union could not by agreement reduce the individual's right of association. ${ }^{151}$

Reluctance to protect the Syndicalists, however, did not disappear. In 1945, an employer who had discharged a Syndicalist under an

145 AD $1955: 16$.

146 See Sch midt, Labour 142.

147 Normally two representatives of LO sit as labor members, but in cases involving salaried employees a representative of TCO sits as a substitute for one of the labor members. Labor Court Act §4, cited in Schmidt, Labour 246.

148 The cases have been analyzed fully with particular emphasis on the positions taken by the various members of the Labor Court in GeIJER \& Sch MIDT, ARBeTAGIvare OCH FACKFÖRENINGSLEDARE I DoMARSÄTE 90-111 (1958).

149 AD $1937: 73$; AD $1937: 88$ (dissenting opinions).

150 AD 1939:24.

151 Right of Association Act $\S 3$; see SOU 1939:49, at 68-69. 
organization clause argued before the Labor Court that he had never urged the employee to leave the Syndicalist union, but only to join the LO union, and that the worker could legitimately belong to both unions. The union and employer members of the court overrode the public members and held that requiring an employee to join the LO union did not violate his right to belong to the union of his choice so long as he was not required to leave the Syndicalist union. ${ }^{152}$ In a subsequent case, the Syndicalists argued that double membership was prohibited by their local rules, and that these rules had been declared valid and binding by the central organization. This, however, proved to be no obstacle for the union and employer members of the court since they felt free to overrule the Syndicalists' interpretation of their own constitution, and declare the local rule void. ${ }^{153}$ The public members uniformly dissented in these cases and pointed out that double membership was meaningless. It subjected the employee to conflicting demands of loyalty and solidarity, created a risk that he would be distrusted and harassed, and required him to pay double union dues. Therefore, compelling him to join the LO union, in practical terms, interfered with his right to belong to the Syndicalists and to work for the building of that union.

These cases caused the Syndicalists to lodge a protest with the Solicitor of Justice (Justitieombudsman) that organizational bias was dominating judicial decisions. The Solicitor, after inquiry, declared that the decisions conflicted with the underlying reasons for protecting the right of association and rested on assumptions so divorced from reality that they ought not to be seriously entertained. He recommended that the statute be amended to expressly overrule these decisions. ${ }^{154}$ Before parliament could act, however, another double membership case came before the Labor Court. The union and employer members now voted unanimously to overrule the prior cases and adopt the position of the public members and the Solicitor. ${ }^{155}$

Although the specious concept of double membership was thus laid to rest, the unwillingness of the Labor Court to protect the Syndicalists from overreaching by the LO union persists in the "measuring monopoly" cases. In the building industry, workers are paid on a group piece rate incentive system, with "measuring men"

152 AD 1945:35; AD 1945:36; AD 1945:77; AD 1946:41. In the last case, one employer member expressed grave doubts about this position, but found that it did not violate a strict construction of the statute and voted with the other union and employer members.

153 AD 1946:59; AD 1946:64.

154 JO's ÄMBETSBERÄTTELSE 1948, at 185.

155 AD 1948:21. See also AD 1950:27; AD 1954:15. 
appointed by the employees and employers to apply the often complex and uncertain formulas and jointly determine the total wages due the group. Prior to 1946, each work group had full freedom to choose its own measuring man, and usually chose one from the union representing the majority of workers in the group, his fee being paid by the members of the group. In 1946, the LO unions in the building industry succeeded in negotiating agreements with the employers' associations requiring that all employee measuring men be members of the $\mathrm{LO}$, and that the fee be deducted from the wages of the group and paid to the LO measuring office. ${ }^{156}$ These provisions were applicable even though none of the workers in the group were members of the LO union. ${ }^{157}$ The stated purpose of these provisions was to insure compliance with the contract, but it was generally understood to be aimed in part at the Syndicalists who had measuring offices.

The Syndicalists did not obtain protection from the Labor Court. They claimed that the employer's refusal to engage in joint measuring with the Syndicalist measuring man deprived their members of the right to be represented by their own union. Despite the fact that the measuring men often discussed questionable items and negotiated differences to reach an agreement, the court held that measuring was not negotiation in a proper sense, but only a technical procedure for obtaining evidence of the nature and amount of work performed. ${ }^{158}$ Second, the Syndicalists also claimed that deducting the measuring fee from their wages and paying it over to the LO union prevented them from using their own measuring office without paying a double fee. The court, however, saw nothing wrong in an employee's being required to pay for this "technical procedure" in determining his wage, even though it was done by a competing union. ${ }^{159}$ The Syndicalists further proved that the amounts paid to the LO unions as measuring fees exceeded the actual cost of measuring, and that the surplus was being used for general union purposes. This, the court admitted, was a violation of the right of association, for Syndicalists were thereby compelled to support the LO unions-the same vice as double membership. However, since the employer did not know that the amount was in excess of actual measuring costs, he could not be found to have

156 The history of this provision and its application are recounted in AD 1960:16.

157 AD 1946:51. The Syndicalists sued the employers to recover the amount paid over to the LO union, but the court held that the LO collective agreement established a usage at the work place which became a part of the syndicalists' employment contract. They had therefore impliedly agreed that the amount should be deducted from their pay and paid over to the LO union! 1948 N.J.A. 1. This decision has been questioned in Schmidt, TJÄNSTEAvTALET 64-65 (1958).

158 AD 1947:50 (one public member dissenting).

159 AD 1948:78 (one public member dissenting). 
violated the Syndicalists' right of association. ${ }^{160}$ Subsequent decisions have solidified LO's measuring monopoly, requiring Syndicalists in effect to be represented by, and to support, the LO union. ${ }^{161}$

Although the Freedom of Association Act purports to protect the individual's right to join and support the union of his choice, the Syndicalist cases make clear that the law in fact provides little protection. This derives partly from the wording of the statute and partly from the Labor Court's restrictive application of it. Both, however, have common roots-the pervasive influence of the dominant labor and employer organizations on the process of lawmaking. In 1936, LO succeeded in removing from the proposed statute a provision expressly protecting the right to remain outside a union, and in 1940 succeeded in making explicit the limited protection of the right of association. Although SAF initially championed the rights of the nonmember, it did not press for any wider definition of the statutory right. ${ }^{162}$ In the Labor Court, the representatives of the collective parties have tended to shape the law to protect their collective interests. ${ }^{163}$ When confronted with competing unionism, their interests unite. The employers do not welcome the friction and disruption that comes with rival unions, but prefer bargaining with a single union for all employees. The SAF, with its system of centralized bargaining and national agreements, is especially hostile to the Syndicalist creed of local autonomy. The employers' hostility to the Syndicalists is only a little less than that of the LO unions. The public members of the Labor Court, constantly confronted with the view of both sides that competing unionism is disruptive of the collective bargaining system, may lose their enthusiasm for protecting this fragmentary organization beyond what is required by the clear words of the statute. As a result the rights of the individual may be submerged by the collective interests.

The historic opposition of SAF to union security agreements might seem at first glance to lead it to favor legal limitations on

$160 \mathrm{AD} 1954: 19,20$. As the result of this decision, the Syndicalists sued the LO union and the employer for the amount improperly deducted from their pay. They recovered a judgment against the union of 70 crowns and costs of 5,500 crowns but were ordered to pay the employer's costs of more than 2,500 crowns.

161 See AD 1960:16, where the Labor Court upheld the LO's levy of a flat 4\% measuring charge on all jobs, even those of Syndicalists which were relatively simple and required little effort or technical skill. These measuring monopoly cases have been sharply criticized in SchmIDT, LABOUR 140-41.

162 See SOU $1939: 49$, at 30.

163 As pointed out in Geijer \& Schmidt, op. cit. supra note 148, at 109, "In the organization clause cases and the cases concerning measuring fees it stands out clearly that the layman members certainly have an interest that the right of association be protected, but not to such an extent that it encroaches on the LO organizations' organizing efforts. The right of association stands out as an exclusive protection for the LO affiliates." 
organization clauses. However, its ability to maintain essentially intact the policy of section 23, and particularly to block at the bargaining table any demands for organization clauses, makes aid from the law quite unnecessary so far as its members are concerned. The existence of such clauses outside SAF is no threat and of little concern, for unions neither hope nor press for any change within SAF in this regard. Able to protect its management prerogatives at the bargaining table, SAF does not seek to protect individual rights by law.

\section{Legal Limitations on Union Security in the United States}

In the United States, legal limitations on union security clauses or the use of economic force to obtain such clauses have followed no stable or consistent pattern. At the turn of the century, a number of state courts condemned the closed or union shop as creating a monopoly, and enjoined strikes and picketing to achieve such objectives. ${ }^{164}$ This reflected less a concern for the rights of the individual than a general judicial hostility to unions and collective action. As this hostility gave way to judicial acceptance of collective bargaining and tolerance of resort to economic force, the attitude toward union security softened. Courts in some states, particularly highly industrialized states such as New York, completely reversed their position, giving the union full freedom to obtain and enforce closed shop agreements; ${ }^{165}$ the Massachusetts courts recognized such contracts as enforceable, but enjoined any use of economic force to obtain them. ${ }^{\mathbf{1 6 6}}$ Other courts, however, continued their rigid rejection of all union security. ${ }^{167}$ In 1935, when Congress passed the National Labor Relations Act, the law on this point was a patchwork of varying state rules, with a substantial number, if not a majority, of states placing strict limitations or prohibitions on union security agreements. ${ }^{168}$

The broad declaration in Section 7 of the NLRA of the right of employees to join unions and to bargain collectively "through repre-

164 See, e.g., Connors v. Connolly, 86 Conn. 641, 86 Atl. 600 (1913); O’Brien v. People, 216 Ill. 354, 75 N.E. 108 (1905); Berry v. Donovan, 188 Mass. 353, 74 N.E. 603 (1905) ; Erdman v. Mitchell, 207 Pa. 79, 56 Atl. 327 (1903).

165 Compare Curran v. Galen, 152 N.Y. 33, 46 N.E. 297 (1897), with Williams v. Quill, 277 N.Y. 1, 12 N.E.2d 547 (1938). See also Cohen \& Roth Elec. Co. v. Bricklayers Union, 92 Conn. 161, 101 Atl. 659 (1917).

166 Hamer v. Nashawena Mills, Inc., 353 Mass. 160, 52 N.E.2d 22 (1943); Fashioncraft, Inc. v. Halpern, 313 Mass. 385, 48 N.E.2d 1 (1943).

167 Canter Sample Furniture House, Inc. v. Retail Furniture Employees, 122 N.J. Eq. 575, 196 Atl. 210 (Ch. 1937). See genera $\rightarrow$ Despres, The Collective Agreement for the Union Shop, 7 U. CHI. L. Rev. 24 (1939).

168 Closed shop agreements, however, were legal in most of the industrial states where organization was more extensive, so that the majority of unions could legally have union security agreements. 
sentatives of their own choosing," and the specific prohibition of section 8(3) against discrimination in employment "to encourage or discourage membership in any labor organization," would have outlawed all union security agreements. However, the central purpose of the statute was to protect unions from employer attacks and to promote the process of collective bargaining. Outlawing union security agreements would have deprived unions of an existing device for self-protection and unsettled established collective agreements. Therefore, section 8(3) was qualified so it would not preclude an employer from making a union security agreement with the union representing his employees. This limitation on the individual's freedom was closely circumscribed by the National Labor Relations Board and the courts. Discharges of nonunion employees must be based on an explicit provision in the collective agreement, not on an informal understanding or practice; ${ }^{169}$ and the agreement must be with a majority union which had obtained its majority without a union security clause or other aid from the employer. ${ }^{170}$ Nor could an employee be discharged because he had been expelled by the union for supporting a rival union during a campaign preceding a Board election. ${ }^{171}$ The collective parties could not by their agreement interfere with the individual's freedom in choosing the majority representative. Even within these limits, union security agreements, or strikes or picketing to achieve them, were subject to the restrictions imposed by the patchwork of state laws. ${ }^{172}$

In the public discussion and legislative debates prior to the passage of the Taft-Hartley Act in 1947, union security was one of the critical issues. The Senate Committee on Labor observed that, in spite of state rules, over 70 percent of all collective agreements contained union security provisions, and then declared: "Abuses of compulsory membership have become so numerous there has been great public feeling against such arrangements." ${ }^{173}$ Among the claimed abuses were union monopoly over available work to the detriment of nonunion workers; threats of expulsion and consequent loss of job by union leaders to silence criticism within the union, eliminate opposition leaders, and curb the political freedom of members; and

169 South Atlantic SS. Co. v. NLRB, 116 F.2d 480 (5th Cir. 1941).

170 NLRB v. Electric Vacuum Cleaner Co., 315 U.S. 685 (1942).

171 Wallace Corp. v. NLRB, 323 U.S. 248 (1944) ; Rutland Court Owners, Inc., 44 N.L.R.B. 587 (1942). The Rutland Court doctrine was ultimately overruled by the Supreme Court as beyond the Board's power under the Wagner Act, ColgatePalmolive-Peet Co. v. NLRB, 338 U.S. 355 (1949), but by this time the TaftHartley amendments had made the protection explicit.

172 Algoma Plywood \& Veneer Co. v. Wisconsin Employment Relations Bd., 336 U.S. 30 (1949).

173 S. REP. No. 105, 80th Cong., 1st Sess. 5 (1947). 
deprivation of management's choice of the workers it hires. ${ }^{174}$ At the same time, it was recognized that the majority union which acted as bargaining representative and had the statutory duty to represent all employees in the bargaining unit was entitled to financial support by all who shared in the benefits.

In attempting to reconcile the intersecting interests of the individual, management, and the union, Congress replaced the proviso of section 8(3)-now 8(a) (3) -with a verbally snarled proviso which has the effect of barring all forms of union security, except what might be roughly termed "compulsory dues." The statute clearly outlaws the closed shop or union preference which makes original hiring depend on union membership, since employment cannot be conditioned on membership until thirty days after employment begins. Even after the thirty days the employee cannot be discharged if "membership is denied or terminated for reasons other than the failure of the employee to tender periodic dues and initiation fees uniformly required." In applying the statute, the National Labor Relations Board has narrowly restricted the obligations which the union can impose on unwilling employees. Thus, the Board has held that an employee who refused to sign an application for membership, appear at a union meeting, or take an oath of loyalty to the union could not be discharged under a union security agreement if he tendered the regular dues and initiation fees. ${ }^{175}$ Nor can he be discharged because he was expelled from the union for refusal to pay special assessments or fines, failure to attend union meetings, strike breaking, or working for a rival union. ${ }^{176}$ In short, the individual cannot be compelled to join the union, to participate in union activities, or obey union rules. ${ }^{177}$ However, he can be compelled to contribute financial support to the union which serves as his statutory representative. ${ }^{178}$

The underlying policy that the majority union was entitled to financial support from those for whom it bargained was only grudgingly and partially accepted. The union's right to compel financial support was made dependent first on state law. Section 14(b) of the statute expressly preserved the power of each state to prohibit the execution

$174 \mathrm{Id}$. at 6.

175 See Union Starch \& Ref. Co., 87 N.L.R.B. 779 (1949), enforced, 188 F.2d 1008 (7th Cir. 1951).

176 NLRB v. Bell Aircraft Corp., 206 F.2d 235 (2d Cir. 1953); Miami Valley Carpenters' Dist. Council, 129 N.L.R.B. 517 (1960); American Bakery \& Confectionary Workers, 128 N.L.R.B. 937 (1960); Electric Auto-Lite Co., 92 N.L.R.B. 1073 (1950), aff'd, 196 F.2d 500 (6th Cir. 1952), cert. denied, 344 U.S. 823 (1952).

177 See Toner, The Taft-Hartley Union Shop Does Not Force Anyone To Join A Union, 6 LAB. L.J. 690 (1955).

178 If he is denied membership or expelled it seems he would not be compelled to support the union financially. 
and application of all forms of union security agreements. This has spawned a series of campaigns for the enactment of state "right to work" laws, the primary impact of which would be to outlaw the "compulsory dues" agreements permitted by the federal statute. ${ }^{179}$

The union's right to financial support is further dependent on its obtaining a union security agreement from the employer. ${ }^{180}$ This may be extremely difficult, even though the employer has only a minimal interest of his own at stake. His freedom to choose new employees is in no way curtailed by a union security clause, and his freedom to retain employees is not subject to veto by the union. His management prerogatives are restricted only to the extent that he cannot retain those few employees who, out of principle or neglect, fail to pay the union dues. Thus, in bargaining over union security, the employer is bargaining over the competing claims of the union and the individual. The drafters of the statute conceived of the employer as the protector of the individual against the union, but employers have not proven themselves guardians of the workers' rights or pocketbooks. Employer resistance to a union security clause, if it does not flow from fear of union strength, may be but a bargaining tactic, enabling the employer to trade union security for some economic concession. The individual's obligation to support the union thus becomes an employer's weapon on the bargaining table, for which the union, and ultimately those it represents, must pay a price.

The statute, by prohibiting even compulsory dues during the first thirty days of employment, destroyed much of the practical value of a union security clause in those industries in which employment is typically short term. ${ }^{181}$ However, under the 1959 amendments, union security clauses in the building and construction industry can require "membership"-that is, dues payment-after seven days. ${ }^{182}$ Dock

179 For some sample discussions of this controversy see AFL-CIO, UNION Security: The Case Against the Right To Work Laws (1958); Meyers, Right To Work in Practice (1959); Sultan, Right-To-Work Laws: A Study in Conflict (1958); Pollitt, Right To Work Law Issues: An Evidentiary Approach, 37 N.C.L. Rev. 233 (1959).

180 The Taft-Hartley Act provided that before negotiating a union security clause a majority of all the employees in the unit must have voted for such a provision in an election held by the Board. In the first three years of the statute, 45,000 such elections were held and the unions won 97\%. 16 NLRB ANN. REP. 10 (1951). Congress then removed this requirement from the law. However, there still remains the provision in section $9(\mathrm{e})$ that if $30 \%$ of the employees petition the Board it shall hold an election to determine whether the union should be decertified. This has not been extensively used, but the union's record in these elections has been progressively poorer. Morgan, The Union Shop Deauthorization Poll, 12 IND. \& LAB. ReL. Rev. 79 (1958).

$\rightarrow$ Note, Special Labor Problems in the Construction Industry, 10 Stan. L. Rev. 525 (1958).

182 Labor-Management Reporting and Disclosure Act § 705, 73 Stat. 545 (1959), 29 U.S.C. \$158(f) (Supp. IV, 1962); Aaron, The Labor-Management Reporting and Disclosure Act of 1959, 73 Harv. L. Rev. 1086, 1112 (1960). 
workers are now hired largely through hiring halls and must join thirty days after their first assignment.

Union security under Taft-Hartley contains a potential element of double membership like that ultimately rejected by the Swedish Labor Court. A member of one union can be compelled to contribute to a rival union which has a union security agreement. He may be burdened with double dues, but here the similarity ends. He need not give the rival majority union any loyalty, and in fact can actively work against it, for expulsion cannot lead to discharge. The double financial burden has not proven a serious impediment to activity on behalf of the minority or outside union. A new representation election is available within three years, with an opportunity to unseat the rival and void its union security agreement. The Swedish employee subjected to double membership had no such freedom of action, for violation of union rules could lead to discharge. Furthermore, he had no opportunity to escape by winning over a majority of his fellow employees, for there was no procedure for unseating the dominant union. He had no prospect but continued subjection to the double burden.

The Swedish "measuring monopoly" agreements in the building industry bear much closer resemblance in purpose and impact to the Taft-Hartley union shop. The Swedish union, by such a clause, becomes the exclusive bargaining representative in measuring the work done, and is able to require each employee to bear his share of the costs. This is the "compulsory dues" logic of Taft-Hartley. However, the Swedish union can only charge for costs of the particular bargaining services, whereas the American union can charge "regular periodic dues" which may include amounts for education, recreation, charities, and other activities remote from the bargaining process. ${ }^{183}$ A more critical distinction is that the Swedish union's right to represent, and exact a charge for representing, does not rest on a majority choice of the employees in the work group. Indeed, the employers agreed that the LO unions should control the measuring even though all the employees in the work group were members of a competing union, and in addition, the law provides no procedure whereby they can escape this monopoly control. The union's right to financial support in the United States rests on its majority status; in Sweden it rests solely on the employer's consent.

The union security device which has caused the most difficult legal problems under Taft-Hartley is the agreement that the employer

183 There is doubt whether it can include amounts spent by the union for support of political candidates or political activities with which the individual disagrees. See International Ass'n of Machinists v. Street, 367 U.S. 740 (1961) ; Brotherhood of Ry. Clerks v. Allen, 373 U.S. 113 (1963). 
shall hire employees through the union-operated hiring hall. Such hiring halls have been integral parts of collective bargaining structures in a number of industries, particularly construction, maritime, stevedoring, and some portions of trucking where employment is typically short term. ${ }^{184}$ They served as private employment agencies to bring together workers seeking jobs and employers in need of workers. They provided a system of job priority in those industries in which short term employment made ordinary seniority arrangements inapplicable. Normally the hiring hall was combined with the closed shop, and union members were referred to jobs on a rotation basis. Union membership was often limited to the number who could be regularly employed, and during busy seasons when all union members were employed, nonunion workers were assigned to vacancies upon the payment of a permit fee. The hiring hall thus provided a rough form of industrial seniority, giving priority to union members who were presumably those permanently attached to the industry. ${ }^{185}$ Finally, by control of job assignments through the hiring hall, the union could compel compliance with all union rules and financial obligations, either by the threat of expulsion or the more subtle method of manipulating job assignments.

Taft-Hartley clearly outlawed the traditional closed-shop hiring hall arrangement. Even though the collective agreement contains no closed shop clause, if the employer agrees to hire only those referred to him by the union, and the union refuses to refer nonmembers, the statute is clearly violated. The problem arises when there is no proof that the union has refused to refer nonmembers. Although there is no evidence of actual discrimination against nonmembers, workers may believe that they will in fact fare better at the hiring hall if they are good union members. The employer's insistence that they be "cleared" by the hiring hall interferes to this extent with their free choice of unions and encourages them to join the one with the hiring hall agreement. From this it might be concluded that all such hiring hall agreements were prohibited. However, the legislative debates indicated that although Congress considered union hiring halls prime offenders in coercing workers and closing the labor market, it also recognized that they were highly useful in devising rational employment

184 See Goldberg, The Maritime Story (1958); Larrowe, Maritime Labor Relations on the Great Lakes (1959); Larrowe, Shape-up and Hiring Hall (1955); Craig, Hiring Hall Arrangements and Practices, 9 LaB. L.J. 939 (1958); Fenton, Union Hiring Halls Under the Taft-Hartley Act, 9 LAB. L.J. 505 (1958); Rains, Construction Trades Hiring Halls, 10 LAB. L.J. 363 (1959).

185 See Toner, The Closed Shop (1942); Blumrosen, Legal Protection Against Exclusion From Union Activities, 22 Oнro St. L.J. 21, 34-36 (1961); Sherman, Legal Status of the Building and Construction Trades Unions in the Hiring Process, 47 Geo. L.J. 203, 217-19 (1958). 
systems in casual labor industries such as construction, stevedoring, and shipping. ${ }^{186}$ Congress did not intend to outlaw all hiring halls, but it gave no guidance on the question of how a union hiring hall could be operated without unlawfully encouraging those seeking work to join the union.

Ten years after the statute was passed, the NLRB finally confronted this dilemma, and in its famous Mountain Pacific ${ }^{187}$ decision held that even though no actual discrimination was shown, the very making of a hiring hall agreement was a violation of the act unless it met three standards. To be legal the collective agreement must explicitly provide that (1) referrals to jobs shall be without regard to union membership; (2) the employer retains the right to reject any worker referred by the union; and (3) notices are to be posted at the hiring hall stating the nondiscriminatory standards for referrals. Failure to include these safeguards in the collective agreement made both the union and the employer subject to the so-called "BrownOlds ${ }^{188}$ remedy" requiring them to pay back to the workers employed through the hiring hall all of the union dues collected during a sixmonth period. ${ }^{189}$

The first and third Mountain Pacific requirements are obviously designed to reduce the fear on the part of workers that the union's control of hiring will be used to discriminate against those who are not members in good standing. The second requirement, however, serves no such purpose, for the employer's right to reject any worker referred by the hall gives no protection to those denied referral. The union still controls a gate on the path to employment. This requirement does not protect the worker's right to choose his union, but rather the employer's right to choose his employees. Section 8 (a) (3) was read as prohibiting not only encroachments on the individual's freedom of association, but also limitations on management prerogatives. The evil, in the eyes of the Board, was the "surrender of the normal management hiring prerogative to the union"; ${ }^{190}$ this

186 The legislative history of Taft-Hartley tends to suggest that the proponents of the legislation viewed hiring hall agreements as inherently discriminatory and inseparable from the closed shop. See Note, Unilateral Union Control of Hiring Halls: The Wrong and the Remedy, 70 YALE L.J. 661 (1961). However, three years later Senator Taft asserted that the statute was not intended to outlaw all hiring hall arrangements but only those which were operated to create a closed shop. S. REP. No. 1827, 81st Cong., 2d Sess. 12-20 (1950).

187 Mountain Pac. Chapter of Associated Gen. Contractors, Inc., 119 N.L.R.B. 883 (1957), rev'd, 270 F.2d 425 (9th Cir. 1959).

188 United Ass'n of Journeymen of Plumbing Indus., 115 N.L.R.B. 594 (1956).

189 See, e.g., Los Angeles-Seattle Motor Express, Inc., 121 N.L.R.B. 1629 (1958), revd, 365 U.S. 667 (1961).

190 Mountain Pac. Chapter of Associated Gen. Contractors, Inc., 119 N.L.R.B. 883, 894 (1957), rev'd, 270 F.2d 425 (9th Cir. 1959). 
the employer was prohibited from bargaining away. ${ }^{191}$ The Board thus imported into the statute a policy akin to that of the Swedish Employers' Federation and sought to impose as a legal rule that which Swedish employers had asserted and achieved by collective bargaining.

The Board's misdirected efforts in Mountain Pacific have now been nullified by the Supreme Court which has made clear that the statute does not prohibit the employer from delegating exclusive control over hiring to the union. ${ }^{192}$ However, the Court has given no intelligible guidance for developing safeguards which will prevent union hiring halls from directly or indirectly depriving workers of their freedom to remain outside the union.

Industries with short term employment and large numbers of employers require some central employment agency "to eliminate wasteful, time consuming and repetitive scouting for jobs by individual workmen and haphazard uneconomical searches by employers." ${ }^{193}$ These needs, however, might be met by devices other than union-operated hiring halls. On the Pacific Coast, the longshore and maritime industries have set up a hiring hall administered jointly by the unions and the employers' association. Joint operation prevents many abuses. However, like the stevedore hiring halls in Sweden, the union in fact retains a veto power over those applying for classification as regular employees. It can thus block the promotion of any individual who is not in the good graces of the union. In New York, the state has operated special hiring halls for dock workers. These halls have provided rational hiring procedures and curbed many abuses. In some other industries, such as the garment trades in which union hiring halls once prevailed, the parties have come to rely on the government employment offices for channelling workers to jobs. In Sweden, the government employment offices have proven quite adequate for rationalizing employment in construction, trucking, and maritime industries, which are even more fragmented than in this country. This alternative to the union hiring hall in these industries has never been seriously tested here. The unions are understandably reluctant; the employers are less understandably passive; and the Government has been customarily lethargic.

In the railroad industry, the union security issue has formed a distinctive pattern. The Railway Labor Act of 1934 adopted the policy of complete freedom of choice for employees to join or not to

191 As indicated above, there were traces in the legislative history of a desire to protect the employer's prerogative in the initial hiring of employees. See note 187 supra and accompanying text.

192 Local 357, Int'1 Bhd. of Teamsters v. NLRB, 365 U.S. 667 (1961).

193 S. REP. No. 1827, 81st Cong., 2d Sess. (1950). 
join a union. ${ }^{194}$ Arguments for allowing the union shop lacked urgency, for only one union had such agreements. Furthermore, it was feared that employers would use such agreements to entrench company controlled unions and freeze out "standard" unions. ${ }^{195}$ As company unions disappeared and standard unions became firmly established, demands for allowing the union shop increased. Finally, in 1951, the act was amended to permit union security agreements similar to those permitted by Taft-Hartley, but with one unique variation. An employee in the operating crafts could comply with the union shop agreement of one union by holding membership in another operating craft union. ${ }^{196}$ This provision, apparently allowing employees to choose between unions, did not reflect any concern for freedom of association, but was devised by the established unions to protect their institutional interests. Operating unions were organized on a craft basis, but the line of promotion and seniority rights cut across craft lines. As employment expands or contracts, employees shuttle from the jurisdiction of one union to another. To require employees to shift their union membership would disrupt the various insurance and benefit schemes which were substantial in these unions; to require double membership would be unduly burdensome. ${ }^{197}$ The solution was strikingly similar to the Swedish pattern, but for entirely different reasons.

Competing unions on the railroads received no protection under the Railway Labor Act. Employees who joined the newly-formed United Railroad Operating Crafts (UROC), a multiple-craft union, were discharged under union shop agreements of the established craft unions, and these discharges were upheld by the courts. ${ }^{198}$ Said the Supreme Court, "The aim of the Section, which was drafted by the established unions themselves, quite evidently was not to benefit rising new unions," 199 nor was its purpose "to allow employees to choose between unions." 200 Rather it was to protect "a group of unions

19448 Stat. 1186 (1934), 45 U.S.C. $\$ 151$ (a) (1958). The statute provided that "no carrier... shall require any person seeking employment to sign any contract or agreement promising to join or not to join a labor organization." 48 Stat. 1188 (1934), 45 U.S.C. $\$ 152$ (5th) (1958). The intention to forbid all forms of union security was reasonably clear. 40 Ops. Aтtr. GEN. 254 (1942).

195 See Toner, The Closed Shop 110-13 (1942).

19664 Stat. 1238 (1951), 45 U.S.C. § 152 (11th) (1958).

197 See Pennsylvania R.R. v. Rychlik, 352 U.S. 480 (1957).

198 See Rose, The Railway Labor Act and the Jurisdiction of the Courts, 8 LAB. L.J. 9 (1957). At least 144 members of UROC lost their jobs and were never reinstate $\rightarrow$ Horton \& Steele, The Unity Issue Among Railroad Engineers, 10 IND. \& LAB. L. Rev. 48, 68 (1956).

199 Pennsylvania R.R. v. Rychlik, 352 U.S. 480, $492-93$ (1957).

200 Id. at $492-93$ n.29. 
already defined and constituted" ${ }^{201}$ and the effect was to confirm the established unions' control.

The railroad shop provision serves to underscore the inherent difficulty of providing legal protection for the individual's freedom of choice within a collective bargaining structure. As both Swedish and American experience testifies, the collective parties-union and management-are not reliable guardians of individual rights. The individual may at most be an incidental beneficiary of the employer's assertion of prerogative, as in the case of SAF's section 23 rejection of organization clauses. Protection of individual rights must come from outside the collective structure; it must be imposed by law. If the collective parties have the political strength to shape the law, or are permitted to write their own legislation, then individual rights will be subordinated to collective institutional interests. If individual rights are adjudicated in tribunals in which the collective parties have an effective voice, then those rights stand in jeopardy. Even neutral parties constantly engaged in adjusting collective interests may come to share the collective parties' sense of values. When the collective interests are compelling, as in the hiring hall situation, the law may simply be flaunted unless it is armed with adequate tools to reshape the collective structure.

\section{Generalizations}

The problem of making meaningful comparisons is compounded when we attempt to draw generalizations. Though we try to view specific legal rules in their social context, we can still focus on but a small segment of legal and social institutions-here freedom of association in collective labor relations. A broader perspective might reveal the distortions of our narrow vision, and to reach for larger generalizations may multiply these distortions. In spite of these dangers, it may be helpful to seek to draw from the material presented some unifying strands which can give added meaning to the details and deeper insight into the underlying problem.

It is apparent that in collective labor relations freedom of association has quite different content in Sweden and in the United States. In Sweden it is the right to organize; it does not include the right to reject collective action. In legal theory the individual has the right to choose his bargaining representative, but in fact it is designated by the employers' association. Most workers can choose which, if any, union they will join and support, but the individual is in fact governed

201 Id. at $495-96$. 
by the collective agreement of the LO or TCO union regardless of his choice. In the United States, freedom of association includes the right to organize, the right to choose between unions, and the right to reject collective action. These are balanced against each other by the principle of majority rule applied in fragmented bargaining units, and the individual may be compelled to support financially the majority union. These three rights are also subject to practical limitations such as employer hostility and unavailability of competing unions, but they still have a substantial measure of reality. In broadest terms, freedom of association in Sweden means full protection of the right to organize; in the United States it means limited protection of free choice.

Implicit in the difference in the content of freedom of association are basically different conceptions of the role of collective bargaining in a democratic society. Sweden is unequivocally committed to collective bargaining as the primary instrument for regulating the labor market. Unions and employers' associations are viewed as the most appropriate institutions, not only to establish rules regulating the employment relation, but also to help develop and implement national economic policies as to wage and price levels, growth rate productivity, and full employment. The thrust of the law, and the pressure of social forces, is to develop organizations on each side capable of fulfilling this governmental function-secure, unified, and inclusive organizations whose legislation by contract can impose order on the labor market. Collective bargaining is thus viewed in Sweden as a fundamental instrument of democratic government, and the organizations tend to acquire a stature comparable to that of institutions of government. The individual who rejects collective bargaining tends to be viewed as one who repudiates government and who denies his responsibility as a citizen. Competing unions tend to be viewed as rivals to the established government.

In contrast, the United States lacks any consensus that collective bargaining is an essential element of democratic government. Although this role of collective bargaining was one of the central premises of the Wagner Act of 1935, and that statute declared the national policy of "encouraging the practices and procedures of collective bargaining," the commitment was a limited one. Groups of workers could vote to reject the collective process. In the Taft-Hartley Act, this commitment became even more equivocal. To the right to join unions and engage in collective action was added in equivalent terms "the right to refrain from any or all such activities," and the use of economic pressure by either union or employer to extend collective bargaining was circumscribed. The central focus was protecting employees' freedom of 
choice; whether they chose collective bargaining was of little concern. Although the Landrum-Griffin amendments treat unions as having governmental characteristics, and impose democratic processes on them, there is no added commitment to collective bargaining as an instrument of democratic government. On the contrary, those amendments reinforced freedom of choice by added restrictions on boycotts and picketing. The dominant attitude of the law and society toward collective bargaining seems to be one of neutrality, if not indifference.

The different directions Swedish and American law have taken in defining freedom of association in collective labor relations have even deeper roots. Large voluntary associations or folk movements have historically played a greater role in Sweden than in the United States. They were one of the major factors in democratizing Swedish society in the last half of the 19th century, and during the present century private organizations have exercised substantial regulatory powers in agriculture, commerce, industry, and other areas. This sharing in governmental power by organizations is considered an essential element in the democratic process. Unlike the situation in the United States, open delegations of government power to private groups is not only permitted but preferred. Out of this has grown a common feeling that individuals ought to join together to promote their common interests, and that there is a social obligation on the individual to support those organizations formed for his benefit. When the law fails to recognize the right not to join, it mirrors the attitude that the individual ought not remain outside this part of the democratic process. In the United States, private power, particularly collective power, has been suspect, and organizations have been feared as distorters of the democratic process. Although private groups in fact wield regulatory-type power, it has been less by the design of conscious social policy than by default, and the independence of the individual remains a primary symbolic value.

It must be emphasized that the purpose of this Article has not been to weigh the relative merits of the two systems of labor relations or to provide any final answers. Rather the purpose has been to probe the complex and stubborn problem which both countries confront-accommodating the rights of the individual within a collective labor system. Comparison clarifies special problems posed by each system and particular points to which further inquiry might be directed. Thus, from the Swedish side, recognition of the dominant unions' control makes clear that if the individual is to have any role within the collective structure, it must be found in his participation in the governmental processes of the union. This emphasizes the importance of vital demo- 
cratic processes within the union which returns to the individual a measure of self-determination. From the United States' side, recognition that freedom of choice is dependent on the size of the bargaining unit might suggest that we reexamine the consequences of bargaining units which fly in the face of economic realities and in effect frustrate freedom of choice. Added awareness that employees in one enterprise, by rejecting collective bargaining, may effectively deny it to employees in competing enterprises, could guide us in designing larger bargaining units which give employees more meaningful freedom of choice. These are but samples which suggest the possible radiations of the comparative study and its function as an intermediate range of inquiry. 